\title{
WHO MOVES THE MALAYSIAN STOCK MARKET- THE U.S. OR JAPAN? Empirical Evidence from the Pre-, During, and Post-1997 Asian Financial Crisis
}

\author{
Rosylin Mohd. Yusof \\ M. Shabri Abd. Majid
}

This paper examines long run co-movements between Malaysian stock market and the two largest stock markets in the world: the U.S. and Japan. Byemploying time-series analysis, i.e., cointegration, variance decompositions, and impulse response functions, the paper seeks to investigate which market actually leads the Malaysian stock market before, during, and after the 1997 Asian financial crisis periods. The results indicate that there is a co-movement of these markets only in the post crisis period. The Japanese stock market is found to significantly move the Malaysian stock market compared to U.S. stock market for the post-crisis period. At the same time, there seems to be a growing proportion of bilateral trade between Malaysia and Japan during the mentioned period. This finding seems to be consistent with the view that the stronger the bilateral trade ties between two countries, the higher the degree of co-movements (Masih and Masih 1999; Bracker et al. 1999; Pretorius 2002; Ibrahim 2003; Kearney and Lucey 2004). Our finding implies that the opportunities of gaining abnormal profits through investment diversification during the post-crisis period in the Malaysian and Japanese stock markets are diminishing as the markets move to- 
Gadjah Mada International Journal of Business, September-December 2006, Vol. 8, No. 3

wards a greater integration. This further implies that any development in the Japanese economy has to be taken into consideration by the Malaysian government in designing policies pertaining to Malaysian stock market.

Keywords: cointegration; diversification benefit; impulse response functions; stock market integration; variance decompositions

\section{Introduction}

Studies on the international stock market integration are proliferating in the financial economics literature. Particularly, the October 1987 stock market crash has spurred the interests of academics, investors as well as policy makers on the issues of the international market integration. The interests have obviously intensified since the 1997 Asian financial crisis which happened a decade later (Janakiramanan and Asjeet 1998). Most studies document that the world's capital markets have increasingly integrated and comovements amongst them are also rising [Goldstein and Michael (1993); Blackman et al. (1994); Corhay et al. (1995); Masih and Masih (1997); and Ghosh et al. (1999)].

The term international market integration represents a broad area of research in financial economics that encompasses many different aspects of the interrelationships across stock markets. The market integration has been defined by many studies either based on asset pricing or on statistical perspective. The perfectly integrated markets, based on the asset pricing view, are by definition obeying the "law of one price" (Klemeier and Harald 2000). The generally accepted definition of market integration is that should two or more markets be integrated, identical securities should be priced identically in these markets (Naranjo and Aris 1997). The rationale is because they have the same risk characteristics regardless of the location in which they are traded (Akdogan 1991; and Cheng 2000). This implies that in a perfect financial integration, there are no barriers (no capital controls and other institutional barriers) that prevent investors from changing their portfolios instantaneously (Lemmen 1998), thus providing no arbitrage opportunities for international investors. Once the markets become integrated, the arbitrage profits should tend to disappear (Akdogan 1991). Meanwhile, based on the statistical perspective, the markets are integrated if prices in national stock markets share a long-run equilibrium relationship. This means that prices in national markets have a tendency to move together in the long run (Cheng 2000). Therefore, this study adopts the statistical view in measuring the stock market integration. 
Mohd. Yusof\& Abd. Majid-Who Moves the Malaysian Stock Market

Many studies on stock market integration in developed countries have been examined. For instance, in a study on the market integration amongst five major markets (U.K., Germany, Netherlands, Japan, and U.S.), Taylor and Tonk (1989) record that U.K. market is cointegrated with other major stock markets after the abolition of foreign exchange control, but not before. Blackman et al. (1994) in their study on 17 world's stock markets, including developed and emerging markets, find that the cointegrating vectors in the 1980's were more than those in the 1970's, suggesting an increasing degree of integration over the period covered in the study. Finally, the integrated market between the two largest markets in the world, the U.S. and Japan, is also documented by Campbell and Hamao's (1992) multifactor asset pricing.

Amongst the studies conducted on the emerging economies, for instance, is the study by Hung and Cheung (1995) on the linkages amongst the stock markets of Hong Kong, Korea, Malaysia, Singapore and Taiwan from 1981 to 1991 . The study finds at least three cointegrating vectors when all indices are denominated in U.S. dollars. In the study on the PacificBasin countries (Australia, Hong Kong, Japan, New Zealand, Singapore, U.S., Indonesia, Malaysia, and Thailand), Janakiramanan and Asjeet (1998) find that U.S. market influences all other markets, except Indonesia, and none of these markets exerts a significant influence on U.S. market.
Although U.S. market influences these markets, the overall influence is diminishing over more recent years. Using a simple correlation approach to the stock markets of U.S., Hong Kong, Malaysia, Singapore and the Philippines, Aggarwal and Pietra (1989) document that there are significant tendencies towards day-to-day linkages between stock price behavior in the U.S. and stock prices behavior in Hong Kong, Singapore, the Philippines, and Malaysia. A more recent study by Cha and Sekyung (2000) on the four Asian emerging equity markets (Hong Kong, South Korea, Singapore, Taiwan) and the two largest stock markets in the world (U.S. and Japan) from 1980 to 1998 document that the links between the two largest equity markets and the Asian emerging markets began to increase after the stock market crash in 1987 and have significantly intensified since the outbreak of the Asian financial crisis in July 1997. These findings are in line with those of Jeon and Von (1990). A study by Jang and Sul (2002) tries, inter alia, to answer the question whether a common trend in Asian stock markets (Thailand, Indonesia, Korea, Japan, Hong Kong, Singapore, and Taiwan) existed before the 1997 financial crisis, and whether the correlations amongst the Asian stock markets increased owing to the crisis. From the cointegration analysis, the study reveals that the comovement amongst Asian stock markets around the 1997 financial crisis has indeed increased. However, this comovement remains strong even af- 
Gadjah Mada International Journal of Business, September-December 2006, Vol. 8, No.3

ter the crisis. Finally, Abd. Majid (2005) examines the interrelationships amongst the ASEAN, Japanese, and U.S. stock markets. He finds that the stock markets in the region are moving towards a greater integration either amongst them or with the Japanese and U.S. stock markets.

Comparing to the enormous research on the developed countries in this area of study, the documentation of stock market integration between Malaysia and the two largest markets in the world, U.S. and Japan, per se seems still inadequate. Much has been postulated and written about the Malaysian market, but limited research is done in the literature of economics and finance on the topic of stock market integration.

In addition, the validity of some results for most of the earlier tests conducted on market integration that are based on certain asset pricing models, such as the Sharpe's (1964) and Lintner's (1965) Capital Asset Pricing Model (CAPM), ${ }^{1}$ Ross's (1976) Arbitrage Pricing Model (APT), consumption-based asset pricing, volatility interaction ${ }^{2}$ and coherence ${ }^{3}$ models have been questioned. These studies rely upon the argument that if markets are integrated, securities with similar risk characteristics should be priced the same regardless of where the securities are traded. This particular argu- ment implicitly assumes away the types of risk usually not considered in the asset pricing models, such as liquidity and country risks (Cheng 2000). In addition, the CAPM requires some restrictive and unrealistic assumptions, such as market equilibrium condition and certain types of utility function for investors. Even though APT model necessitates less restrictive assumptions than does CAPM, it still suffers from misspecification problem, hence the validity of the model has cast some doubt by most researchers. One of the major limitations of this model is that it might overlook some risk factors that affect asset returns. For example, Ingersol (1987) finds that the error variance in the asset pricing models might be due to full-unidentified risk factors. Furthermore, the type of test used in the asset pricing models is a joint test of a specification, which means a rejection of a test could be a failure of either the models or the rejection of market integration hypothesis.

To overcome these shortcomings, recent studies have adopted different approaches to investigating the market integration issues, such as Vector Autoregressive (VAR), Generalised Autoregressive Conditional Heteroskedasticity (GARCH), Granger causality and cointegration analyses. Amongst these econometric tech-

\footnotetext{
${ }^{1}$ This model, for example, has been adopted by Solnik (1974), Stehle (1977), Joiron and Schwart (1986), Wheatley (1988), Campbell and Hamao (1992), to name a few.

2 See Darbar and Deb (1997).

3 This model, for example, has been adopted by Sewell et al. (1996).
} 
niques, cointegration analysis is the most commonly used in exploring the market integration. Therefore this study adopts this approach to addressing the issue of market integration. In addition, Variance Decomposition and impulse response analyses are also adopted to check for the strength of the linkages between Malaysian stock market and the two largest markets in the world, U.S. and Japan. The superiority of the adopted models is believed to be able to overcome the shortcomings of the previous studies on this issue.

Consistent with the studies of Ghosh et al. (1999) on eleven daily stock indices, including nine AsianPacific markets, U.S. and Japan from March $26^{\text {th }}, 1997$ to December 21 st, 1997 and Durand et al. (2001) on the stock market integration amongst seven Pacific-Rim (Australia, Hong Kong, South Korea, Malaysia, Singapore, Taiwan, and Thailand) over the period of December $2^{\text {nd }}, 1985$-December $31^{\text {st }}$, 1996, this study tries to answer the question: who moves the Malaysian stock market: U.S. or Japan? over the period from June $1^{\text {st }}, 1996$ to August $30^{\text {th }}, 2000$. Although this study is similar in aims and title to those of Ghosh et al. (1999) and Durand et al. (2001), but the methodology adopted in our study is of difference. Our study ex- tends the Granger causality and cointegration analyses adopted in the former two studies by including Variance Decomposition and impulse response analyses. Shortly, this study tries to provide a more up-to-date integration evidence on the stock market of Malaysia vis-à-vis those of the U.S. and Japan, hinging on a more superior model of estimation and seeking to analyze market integration at both bivariate and multivariate ${ }^{4}$ levels.

Does the Malaysian market integrate with U.S. and Japan? Who moves the Malaysian stock market-U.S. or Japan? Do the results of this study coincide with the findings of the developed countries? Otherwise, to what extent may the result differ from those of developed economies? Accordingly, this study attempts to partially fill this gap in the literature and to provide recent empirical evidence on the stock market integration between the Malaysian stock market and their interrelationships with the two largest stock markets in the world, U.S. and Japan.

The results of this study indicate whether the Malaysian stock is segmented or whether the international investors can enjoy diversification benefits when allocating their investments across these markets. If stock markets share a long-run equilibrium relationship, which implies that they

\footnotetext{
${ }^{4}$ Focusing only on bivariate or only multivariate cointegration analysis might miss important information because it is possible that variables are not cointegrated at bivariate level but are cointegrated collectively, or vice versa. This was a fatal deficiency of Palac-McMiken's (1997) and Jang and Sul's (2002) studies, to mention but a few, where they only focused on bivariate analysis in exploring market integration amongst the five founding of the ASEAN and selected Asian stock markets, respectively.
} 
have a tendency to move together towards the same direction in the long run, then these markets are integrated and provide no diversification benefits for those who are investing their money in this region. On the other hand, if the stock markets have no tendency to move together in the longrun, then the markets are segmented and provide ample room for diversification benefits for those who are diversifying their investments in these markets. Therefore, having knowledge on market integration is one of key determinant of success for investors, fund management houses, and other institutional investors both at national and international levels who are seeking to diversify their investments and make capital budgeting decisions in these markets. Hence, the results of this study have great importance in assisting financial analysts to make investment decisions and in providing recent empirical evidence on the Malaysian stock market and their interrelationships with the two largest stock markets in the world, U.S. and Japan.

The rest of this study is organized as follows: Section 2 describes the data used in the study. Methodology on which analysis is based is then presented in Section 3. Section 4 in turns discusses the empirical results and some implications of the study. Finally, Section 5 concludes the study.

\section{Data Description}

The data for stock indices for Malaysia, the U.S. and Japan are obtained from the Bloomberg Database. For each stock market, data on daily market indices, measured in local currency terms, are obtained for the following subperiods: ${ }^{5}$

Subperiod 1: the period before 1997 financial crisis (June $1^{\text {st }}$, 1996 to June $30^{\text {th }}$, 1997);

Subperiod 2: the period during the 1997 financial crisis (July $1^{\text {st }}, 1997$ to July $\left.31^{\text {st }}, 1998\right)$;

Subperiod 3: the recovery period 1 (August 1 ${ }^{\text {st }}, 1998$ to August 31 $\left.{ }^{\text {st }}, 1999\right)$; and

Subperiod 4: the recovery period 2 (September $1^{\text {st }}, 1999$ to September $\left.30^{\text {th }}, 2000\right)$.

The stock market indices used in the study are the Kuala Lumpur Composite Index (KLCI), S\&P 500 (S\&P 500), and Tokyo Price Index (TOPIX). ${ }^{6}$

Two problems arise in examining the integration of different stock markets. The first problem lies in the missing observations due to different stock

\footnotetext{
${ }^{5}$ These sub-periods are divided based on economic analysts and observers who dismissed that the financial crisis began with the floating of Thai Bath on July $2^{\text {nd }}, 1997$. A year before this period is referred to as pre-crisis period and two years after the crisis are further divided into two post-crisis periods in order to fully examine how the degree of market integration changes during the post-crisis periods. This is consistent with the study of Jang and Sul (2002).

${ }^{6}$ The main reason of choosing these stock market indices are due to the same method of measurement, which is the average capitalization weighted index.
} 
market holidays. Since the study extensively incorporates lags in the regressions, missing data are particularly troublesome. ${ }^{7}$ Therefore, it is desirable to fill in estimate-based information from an adjacent day. Rather than using a sophisticated interpolation, this study follows the studies of Jeon and Von (1990) and Hirayama and Tsutsui (1998) by adopting the method of Occam's razor (just by filling in the previous day's price). ${ }^{8}$ The second one is the differences in trading hours amongst the international stock markets. For the purpose of our present paper, we adjust for the different trading hours by regressing today's KLCI and TOPIX with yesterday's $($ lag= 1) S\&P 500.

\section{Empirical Framework}

Our empirical approach is based on the recent standard methods of cointegration and vector auto-regressions (VAR). Several studies in both economics and finance literature employ this technique in addition to the standard methods of integration and cointegration. Examples of these studies include Hassan et al. (2001), Ibrahim (2003) and Ahmed and Tongzon (1998). Like these studies, we adopt this approach for various reasons. The method is simple where one does not have to worry about mak- ing a priori distinction between exogenous and endogenous variables. According to Sim (1980), the distinction is often subjective and therefore it is wise to treat them on an equal footing. Moreover, this technique sets no restrictions on the structural relationships of the economic variables and hence, misspecification problems may be avoided. Finally, the variance decomposition and impulse response functions derived from VAR allow us to assess the strength and direction of variables in the system.

Our analysis starts with uncovering the integration and cointegration properties of the variables before working with an unrestricted vector auto regression (VAR) model (all variables in this VAR system become endogenous and therefore specify a relatively unrestricted dynamic process). The results from cointegration tests enable us to model short-run dynamic interactions amongst the variables within our VAR system. If the variables are found to be non-stationary and non-cointegrated, the dynamic interactions amongst the variables are assessed according to the standard VAR model with variables expressed in first difference. Conversely, if the variables are found to be cointegrated, error correction models should be employed and accordingly this justifies the use of VAR model in levels.

\footnotetext{
${ }^{7}$ For example, if a regression equation contains six lags; one missing observation would additionally render six subsequent observations be dropped.

${ }^{8}$ Simplistic as it may be, this study justifies this method on the premise that a closed stock exchange does not produce any information on bank holidays. Since no new information is revealed, the previous day's information is carried over to the subsequent day.
} 
Gadjah Mada International Journal of Business, September-December 2006, Vol. 8, No.3

The VAR model is just a multiple time-series generalization of the Autoregressive model. In matrix notation, the VAR model for $\mathrm{k}$ variables can be expressed by the following:

$Y_{t}=A_{1} Y_{t-1}+\ldots A_{p} Y_{t-p}+U_{t}$

where,

$\mathrm{Y}_{\mathrm{t}}=\left(\mathrm{Y}_{1 \mathrm{t}} \mathrm{Y}_{2 \mathrm{t}} \ldots \ldots \ldots \ldots \mathrm{Y}_{\mathrm{kt}}\right)$ and

$\mathrm{A}_{1}, \mathrm{~A}_{2}, \ldots . . \mathrm{A}_{\mathrm{p}}$ are $k x k$ matrix

$\mathrm{Y}_{\mathrm{t}}=\mathrm{a} k$-dimensional vector of errors with $\mathrm{E}\left(\mathrm{u}_{\mathrm{t}}\right)=0$

In a reduced form, the VAR model can be expressed as:-

$$
\mathrm{A}(\mathrm{L}) \mathrm{Y}_{\mathrm{t}}=\mathrm{U}_{\mathrm{t}}
$$

where,

$\mathrm{L}=$ the lag operator.

$\mathrm{Y}=\mathrm{a}$ vector consisting of appropriately transformed variables, and

$\mathrm{U}=\mathrm{a}$ vector of innovations to these variables.

At this juncture, it is also important to note that the estimated results of the VAR model as Equation (2) are easier to interpret in its moving representation, from which variance decomposition and impulse response functions are derived. Here, the strategy involves inverting the estimated model on (2) to derive its moving average representation using Sims' (1980). Accordingly, it also involves orthogonalizing innovations in each variable using Cholesky's decomposition of the residual covariance matrix, imposing a recursive structure on the contemporaneous relationship amongst the variables. Nevertheless, the variance decompositions and impulse response functions generated from this procedure may be sensitive to the ordering of the variables. We shall discuss this further in the empirical results section.

In this present analysis, we start by testing the relationship amongst the stock indices for Malaysia, Japan, and the U.S.

$$
\begin{aligned}
\mathrm{MAY}_{\mathrm{t}}= & \alpha_{0}+\alpha_{1} \mathrm{US}_{\mathrm{t}}+ \\
& \alpha_{2} \mathrm{JP}_{\mathrm{t}}+\mathrm{e}_{\mathrm{t}}
\end{aligned}
$$

where

May $=\quad$ KLCI as a proxy for the Malaysian stock index,

S\&P $500=$ a proxy for U.S. stock index, and

TOPIX $=$ a proxy for the Japanese stock index.

In order to evaluate the interactions amongst the variables, we include the following steps.

\section{Integration Tests}

We begin the analysis by examining the stationarity properties of the data series. Thomas (1997) stresses that classical regression techniques become invalid if applied to variables that do not meet the definition of stationarity. ${ }^{9}$ This study employs the

\footnotetext{
9 The assumption of stationary simply means that for every series, the mean, variance and covariance does not change over time.
} 
standard Augmented Dickey Fuller tests (ADF) and Phillips-Peron tests (PP) unit root tests (Dickey and Fuller, 1979 and 1981; Phillips and Perron 1988) with and without time trend to test for stationarity. The tests will be based on the following:

$$
\begin{array}{r}
\Delta \mathrm{X}_{\mathrm{t}}=\propto+\beta \mathrm{T}+\rho \mathrm{X}_{\mathrm{t}-1}+ \\
\sum_{\mathrm{i}=1}^{\mathrm{m}} \lambda_{\mathrm{i}} \Delta \mathrm{X}_{\mathrm{t}-1}+\varepsilon_{\mathrm{t}}
\end{array}
$$

where

$X_{t}=$ the variable under consideration,

$\mathrm{T}=$ time trend,

$\Delta=$ difference operator, and

$\mathrm{e}_{\mathrm{t}}=$ i.i.d. disturbance with mean 0 and variance $\sigma^{2}$, that is

$\left[\varepsilon_{\mathrm{t}} \sim \mathrm{N}(0, \mathrm{~s} 2)\right]$

It is required that we test whether the estimated value for $\rho$ is significantly less than 0 . If the finding rejects the hypothesis that $\rho=0$, the series is concluded to be stationary. The PP test for unit roots will be conducted in a similar manner using the above analysis without the lagged first differenced terms. The test statistics also correct for some serial correlation and heteroskedasticity in the residuals. If, however, the variables are found to be non-stationary, in conventional regression models one would typically differentiate non-stationary variables be- fore utilizing them in her further analysis.

\section{Cointegration Tests}

Having established that each of the series is non-stationary, we will then proceed to examine whether some long-run equilibrium relationships exist amongst the stock indices for Malaysia, Japan, and the U.S. Formally stated, a set of variables is said to be cointegrated if they are individually non-stationary and integrated of the same order, and yet their linear combination is stationary. If two or more of stationary time-series share a common trend, then they are said to be cointegrated. In statistics, the presence of cointegration rules out noncausality amongst the variables examined. In econometrics, this suggests error correction models and Granger causality tests to capture both the shortrun dynamics and the long-run equilibrium in the regression (Engle and Granger 1987).

The two most widely used tests for cointegration are the Engle-Granger (1987) two-step estimator and the Johansen (1988) and Johansen and Juselius (1990) maximum likelihood estimator. Both tests are then shortly called EG and JJ. Compared to EG two-step approach, the JJ procedure poses many advantages in testing for cointegration. ${ }^{10}$ This study therefore

\footnotetext{
${ }^{10}$ Amongst the superiorities of the JJ procedures over EG two-step approach are: the JJ test does not assume a priori that the existence of at most a single cointegrating vector and instead, it explicitly tests for the number of cointegrating relationships; the JJ test is not sensitive to the choice of dependent variables as it assumes all variables are endogenous (Masih and Masih 1997).
} 
Gadjah Mada International Journal of Business, September-December 2006, Vol. 8, No. 3

employs maximum likelihood approach of Johansen and Juselius (1990) to test the cointegration.

\section{Bivariate and Multivariate Causality Tests}

To examine the causal nexus between the Malaysian stock and two most developed markets, U.S. and Japan, the error correction model (ECM) is employed. According to Granger representation theorem, for the cointegrated series, we need to employ the ECM. This error correction term (ECT) is included in the case of cointegration; otherwise it is omitted from the regression.

This study examines the interrelationships amongst the markets using both bivariate and multivariate frameworks. In bivariate case, the causal nexus is only examined between the twomarkets whilst in multivariate case, the causality model includes all the variables namely KLCI, S\&P 500, and TOPIX. Following Malliaris and Urrutia (1992) and Sheng and Tu (2000), the study makes the following adjustments for causality tests. Suppose that a major world event occurs in the Malaysian and Japanese stock markets and is announced at certain point in time on a given trading day, the closing price of the same trading day on U.S. stock markets will reflect this information. This illustrates that closing prices on day $t$ in the Malaysian and Japanese stock markets affect closing prices in New York on the same calendar day $t$. Thus, a Granger regression exploring whether the Malaysian and Japanese stock markets lead the US stock market can be, respectively, written as follows:

$$
\begin{aligned}
\Delta \mathrm{S} \& \mathrm{P} 50_{\mathrm{t}}= & \alpha_{0}+\sum_{\mathrm{i}=1}^{\mathrm{k} 1} \alpha_{1 \mathrm{i}} \Delta \mathrm{S} \& \mathrm{P} 50_{\mathrm{t}-\mathrm{i}}+ \\
& \sum_{\mathrm{i}=0}^{\mathrm{k} 2} \alpha_{2 \mathrm{i}} \Delta \mathrm{KLCI}_{\mathrm{t}-\mathrm{i}}+ \\
& \sum_{\mathrm{i}=0}^{\mathrm{k} 3} \alpha_{3 \mathrm{i}} \Delta \mathrm{TOPIX}_{\mathrm{t}-\mathrm{i}}+ \\
& \alpha_{4} \mathrm{ECT}_{\mathrm{t}-\mathrm{i}}+\varepsilon_{\mathrm{t}}
\end{aligned}
$$

On the other hand, if important economic news occurs in the U.S., and is released at a certain point in time on a given trading day, the closing price of the next trading day, rather than the same trading day, on the Malaysian and Japanese stock markets will reflect this information. In other words, closing prices on day $t$ in the U.S. may affect closing prices in the Malaysian and Japanese stock markets one day after, $t+1$. Hence, Granger regression postulating that the U.S. leads the Malaysian and Japanese stock markets, after adjusting for time-zone differences, can be formulated respectively as follows:

$$
\begin{aligned}
\Delta \mathrm{KLC}_{\mathrm{t}+1}= & \alpha_{0}+\sum_{\mathrm{i}=1}^{\mathrm{k} 1} \alpha_{1 \mathrm{i}} \Delta \mathrm{KLCI}_{\mathrm{t}-\mathrm{i}}+ \\
& \sum_{\mathrm{i}=0}^{\mathrm{k} 2} \alpha_{1 \mathrm{i}} \Delta \mathrm{S} \& \mathrm{P} 500_{\mathrm{t}-\mathrm{i}}+ \\
& \sum_{\mathrm{i}=0}^{\mathrm{k} 3} \alpha_{2 \mathrm{i}} \Delta \mathrm{TOPIX}_{\mathrm{t}-\mathrm{i}}+ \\
& \alpha_{4} \mathrm{ECT}_{\mathrm{t}-\mathrm{i}}+\varepsilon_{\mathrm{t}}
\end{aligned}
$$


Mohd. Yusof\& Abd. Majid - Who Moves the Malaysian Stock Market

$$
\begin{aligned}
\Delta \text { TOPIX }_{\mathrm{t}+1}= & \alpha_{0}+\sum_{\mathrm{i}=1}^{\mathrm{k} 1} \alpha_{1 \mathrm{i}} \Delta \text { TOPIX }_{\mathrm{t}-\mathrm{i}}+ \\
& \sum_{\mathrm{i}=0}^{\mathrm{k} 2} \alpha_{1 \mathrm{i}} \Delta{\mathrm{S} \& P 500_{\mathrm{t}-\mathrm{i}}+}^{\mathrm{k} 3} \alpha_{2 \mathrm{i}} \Delta \mathrm{KLCI}_{\mathrm{t}-\mathrm{i}}+ \\
& \sum_{\mathrm{i}=0} \alpha_{4} \mathrm{ECT}_{\mathrm{t}-\mathrm{i}}+\varepsilon_{\mathrm{t}}
\end{aligned}
$$

From the equations (5 through 7), two channels of causation may be observed. The first channel is the standard Granger tests, examining the joint significance of the coefficients of the lagged independent variables. Meanwhile, the second channel of causation is the adjustment of the dependent variable to the lagged deviations from the long-run equilibrium path, represented by the ECT. If the ECT is found to be significant, it substantiates the presence of cointegration as established in the system earlier and at the same time; it tells us that the dependent variable adjusts towards its long run level.

\section{Variance Decompositions and Impulse Response Functions}

The Granger causality of the dependent variable within the sample period in VECM framework does not only provide an indication of the dynamic properties of the system but they also do not enable us to capture the relative strength of the causality amongst the variables beyond the sample period. Variance decomposition therefore allows us to examine the out-of-sample causality amongst the variables in the VAR system.

The VAR model is a system of reduced form dynamic linear equations in which each variable is expressed as a function of a serially uncorrelated errors and an equal number of lags of all variables in the system (Abdullah 1998; Enders 1995). This VAR model assumes that the contemporaneous correlations of errors across equations are nonzero; hence, there are no contemporaneous explanatory variables in the model. The error terms (also referred to as innovations) can provide a potential source of new information about the movements in a variable during a current period. In order to interpret economic implications from the VAR model, we use Sim's (1980) innovation accounting procedure. This procedure involves the decomposition of forecast error variance of each variable into components attributable to its own innovations and to shocks of other variables in the system.

The above procedure of variance decompositions together with impulse response analysis (also known as innovation accounting in the literature) allows us to examine the relationships amongst the economic variables. If the correlations amongst the various innovations are huge, the identification problem is likely to be important. The alternative orderings should yield similar impulse responses and variance decompositions. We shall discuss this further in the empirical results section. 
Gadjah Mada International Journal of Business, September-December 2006, Vol. 8, No. 3

\section{Empirical Analysis}

We start our analysis by presenting the descriptive statistics of our data. Table 1 presents a summary of the descriptive statistics of the Malaysian, U.S., and Japanese stock returns for all three markets. Except for subperiod 1, the standard deviation of the Malaysian stock return is higher compared to those of the stock returns in U.S. and Japanese markets. Therefore, it seems that the Malaysian stock market is more volatile compared to the other stock markets. As expected, for most financial time-series distributions, the stock return data for all three stock markets in all subperiods seem to exhibit excess kurtosis, suggesting that the distribution of the stock returns for all three markets are leptokurtic (have a fatter tail than the normal distribution). Finally, the Jarque-Bera statistics for both indices and returns indicate the non-normal distribution of the data series.

Table 2 provides correlation analysis for stock returns for all subperiods. The figures in parentheses indicate the $p$-values testing the null hypothesis that the respective sample correlations are zero. As expected, the correlations amongst the three stock market returns are positively and generally significantly different from zero. In terms of the magnitudes, the KLCI seems to have increasingly high statistical correlations with the S\&P 500 over the period before, during, and the recovery period 1 . However, the correlation seems to be lower in more recent years (recovery period 2), indicating that the KLCI has a reduced correlation with the S\&P 500 during the period after the 1997 financial crisis. This seems to be in reverse for Malaysian and Japanese stock returns. It is interesting to note that KLCI seems to be highly correlated with TOPIX during the period of financial crisis and remained statistically correlated during both recovery periods. At this juncture, we can at least infer that Malaysian stock market seems to exhibit an increasing correlation with the Japanese stock market, particularly the period during and after the 1997 financial crisis.

As mentioned earlier, we seek to analyze the daily stock market returns based on the VAR model proposed by Sim (1980), which allows us to examine the market movements amongst the three stock markets. This method requires that the time-series analyzed be stationary. In Table 3, we report the unit root tests based on the commonly Augmented Dickey Fuller procedure. The lag length for each variable is also presented for both stock market indices as well as for the stock market returns. We conduct both tests with and without time-trend. The first column presents the results for the log levels of the data series and the second column reports the results for their first differences.

The results from Table 3 indicate that for ADF and Phillips-Perron, unit root tests are at log levels. Except for KLCI (in subperiod 2), TOPIX (in 
Mohd. Yusof\& Abd. Majid - Who Moves the Malaysian Stock Market

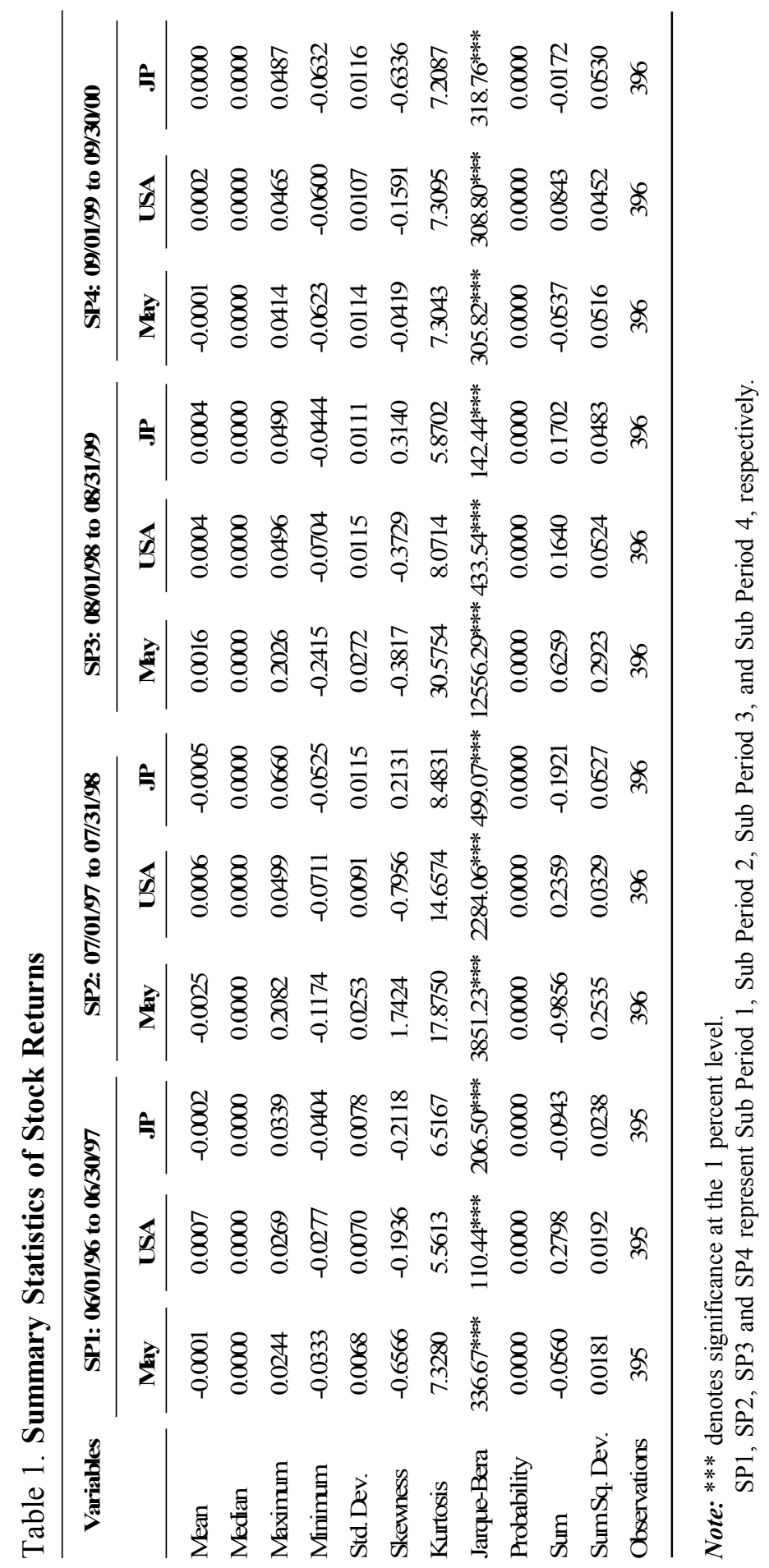


Gadjah Mada International Journal of Business, September-December 2006, Vol. 8, No. 3

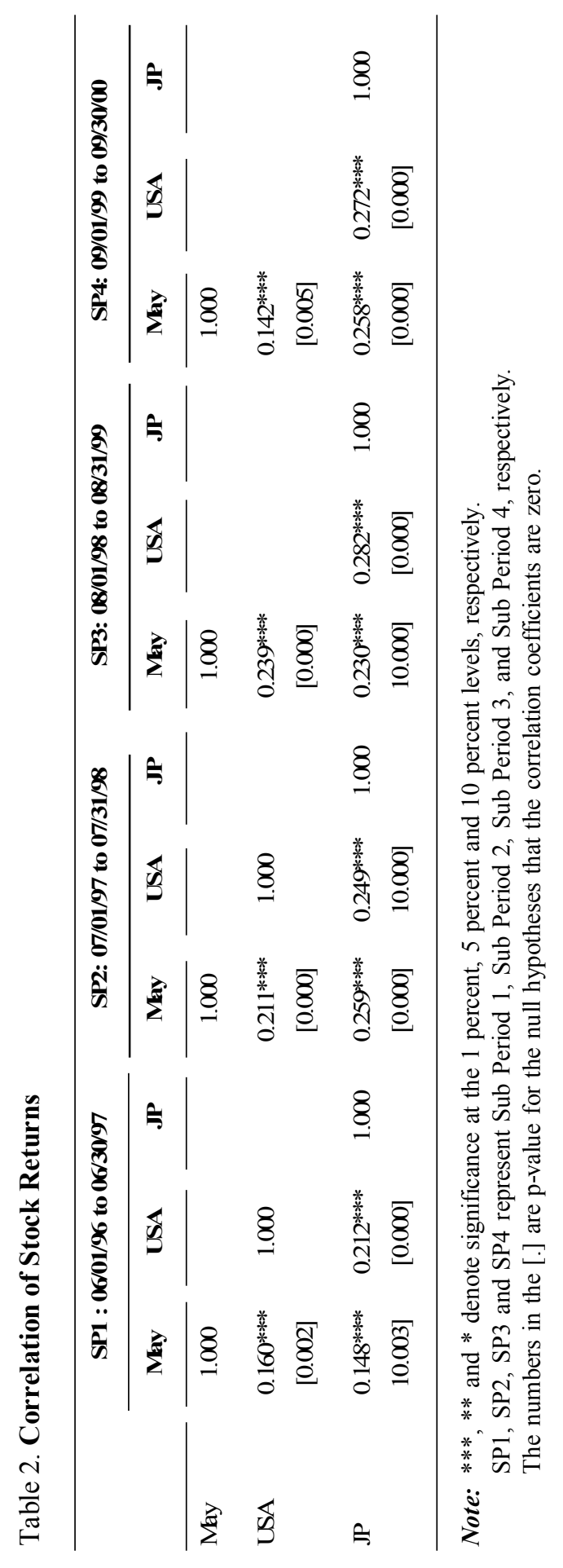


Mohd. Yusof\& Abd. Majid-Who Moves the Malaysian Stock Market

Table 3. Unit Root Tests

\begin{tabular}{|c|c|c|c|c|c|c|c|}
\hline \multirow[b]{2}{*}{ Period } & \multirow[b]{2}{*}{ Variable } & \multirow{2}{*}{$\begin{array}{c}\text { Lag } \\
\text { Length }\end{array}$} & \multicolumn{2}{|c|}{ Level } & \multirow{2}{*}{$\begin{array}{c}\text { Lag } \\
\text { Length }\end{array}$} & \multicolumn{2}{|c|}{ First-Difference } \\
\hline & & & ADF & PP & & ADF & PP \\
\hline \multirow[t]{3}{*}{$\begin{array}{l}\text { Sub-Period 1: } \\
06 / 01 / 96 \text { to 06/30/97 }\end{array}$} & May & 1 & $\begin{array}{l}-1.2639 \\
-0.3052\end{array}$ & $\begin{array}{l}-1.0884 \\
-0.3901\end{array}$ & 0 & $\begin{array}{l}-17.2113 * * * \\
-17.2067 * * *\end{array}$ & $\begin{array}{l}-17.2113^{* * *} \\
-17.2158^{* * *}\end{array}$ \\
\hline & USA & 1 & $\begin{array}{c}-2.6622 \\
2.0191\end{array}$ & $\begin{array}{l}-2.6164 \\
1.9650\end{array}$ & 0 & $\begin{array}{l}-18.5871 * * * \\
-18.4117 * * *\end{array}$ & $\begin{array}{l}-18.5592^{* * *} \\
-18.3973^{* * *}\end{array}$ \\
\hline & JP & 0 & $\begin{array}{l}-0.9586 \\
-0.6254\end{array}$ & $\begin{array}{l}-1.0573 \\
-0.6004\end{array}$ & 0 & $\begin{array}{l}-18.9756^{* * *} \\
-18.9259^{* * *}\end{array}$ & $\begin{array}{l}-18.9650^{* * *} \\
-18.9298^{* * *}\end{array}$ \\
\hline \multirow[t]{3}{*}{$\begin{array}{l}\text { Sub-Period 2: } \\
07 / 01 / 97 \text { to } 07 / 31 / 98\end{array}$} & May & 0 & $\begin{array}{c}-1.8813 \\
-2.0053^{* *}\end{array}$ & $\begin{array}{l}-2.0676 \\
-1.8696^{*}\end{array}$ & 0 & $\begin{array}{l}-18.8883^{* * *} \\
-18.7614^{* * *}\end{array}$ & $\begin{array}{l}-18.9245^{* * *} \\
-18.8424 * * *\end{array}$ \\
\hline & USA & 16 & $\begin{array}{c}-2.6391 \\
1.1278\end{array}$ & $\begin{array}{l}-2.7989 \\
1.6995\end{array}$ & 15 & $\begin{array}{l}-4.9819 * * * \\
-4.007 * * *\end{array}$ & $\begin{array}{l}-21.7589^{* * *} \\
-21.4686^{* * *}\end{array}$ \\
\hline & JP & 2 & $\begin{array}{l}-1.6705 \\
-0.9311\end{array}$ & $\begin{array}{l}-1.8245 \\
-0.9642\end{array}$ & 1 & $\begin{array}{l}-15.8175 * * * \\
-15.7304 * * *\end{array}$ & $\begin{array}{l}-20.2204 * * * \\
-20.0335 * * *\end{array}$ \\
\hline \multirow[t]{3}{*}{$\begin{array}{c}\text { Sub-Period 3: } \\
\text { 08/01/98 to 08/31/99 }\end{array}$} & May & 6 & $\begin{array}{r}-1.8055 \\
1.6886\end{array}$ & $\begin{array}{l}-2.5284 \\
1.3189\end{array}$ & 5 & $\begin{array}{l}-9.1679^{* * *} \\
-7.4541^{* * *}\end{array}$ & $\begin{array}{l}-25.5714^{* * *} \\
-25.4492 * * *\end{array}$ \\
\hline & USA & 1 & $\begin{array}{r}-2.4561 \\
0.7486\end{array}$ & $\begin{array}{l}-2.5854 \\
0.7248\end{array}$ & 0 & $\begin{array}{l}-21.1464 * * * \\
-21.1707 * * *\end{array}$ & $\begin{array}{l}-21.1485^{* * *} \\
-21.1727^{* * *}\end{array}$ \\
\hline & JP & 0 & $\begin{array}{c}-3.4252^{* *} \\
0.7714\end{array}$ & $\begin{array}{c}-3.4249^{* *} \\
0.7762\end{array}$ & 0 & $\begin{array}{l}-19.6379^{* * *} \\
-19.4650^{* * * *}\end{array}$ & $\begin{array}{l}-19.6380^{* * *} \\
-19.4596 * * *\end{array}$ \\
\hline \multirow[t]{3}{*}{$\begin{array}{c}\text { Sub-Period 4: } \\
\text { 09/01/99 to 09/30/00 }\end{array}$} & May & 5 & $\begin{array}{l}-0.5292 \\
-0.2109\end{array}$ & $\begin{array}{l}-0.4534 \\
-0.1345\end{array}$ & 4 & $\begin{array}{l}-8.5383^{* * *} \\
-8.3776^{* * *}\end{array}$ & $\begin{array}{l}-18.6708^{* * *} \\
-18.5831^{* * *}\end{array}$ \\
\hline & USA & 3 & $\begin{array}{c}-3.4403 * * \\
0.2420\end{array}$ & $\begin{array}{c}-3.5189^{* *} \\
0.4076\end{array}$ & 2 & $\begin{array}{l}-12.1842^{* * *} \\
-12.2090^{* * *}\end{array}$ & $\begin{array}{l}-18.6559^{* * *} \\
-18.6517^{* * *}\end{array}$ \\
\hline & JP & 0 & $\begin{array}{l}-2.4024 \\
-0.0915\end{array}$ & $\begin{array}{l}-2.3068 \\
-0.1002\end{array}$ & 0 & $\begin{array}{l}-19.2491 * * * \\
-19.2485 * * *\end{array}$ & $\begin{array}{l}-19.5026^{* * *} \\
-19.4177^{* * *}\end{array}$ \\
\hline
\end{tabular}

Note: ${ }^{* * *}, * *$ and $*$ denote significance at the 1 perfcent, 5 percent and 10 percent levels, respectively. The lag lengths included in the models are based on the Akaike Information Criteria (AIC). The tests of ADF (Augmented Dickey-Fuller) and PP (Phillips-Perron) are based on two models: (1) with constant and trend; and (2) without constant and trend.

subperiod 3), S\&P 500 (in subperiod 4 ), all series contain unit root. This means that the null hypothesis of the presence of unit root cannot be rejected even at 10 percent significance level. However, both ADF and PP consistently suggest that all data are stationary at first differentiated and there- fore indicating that all the variables are $I(1)$.

\section{Cointegration Analysis}

Having concluded that each of the series is stationary at first differentiated, we proceed to examine whether a long-run equilibrium exists amongst 
Gadjah Mada International Journal of Business, September-December 2006, Vol. 8, No. 3

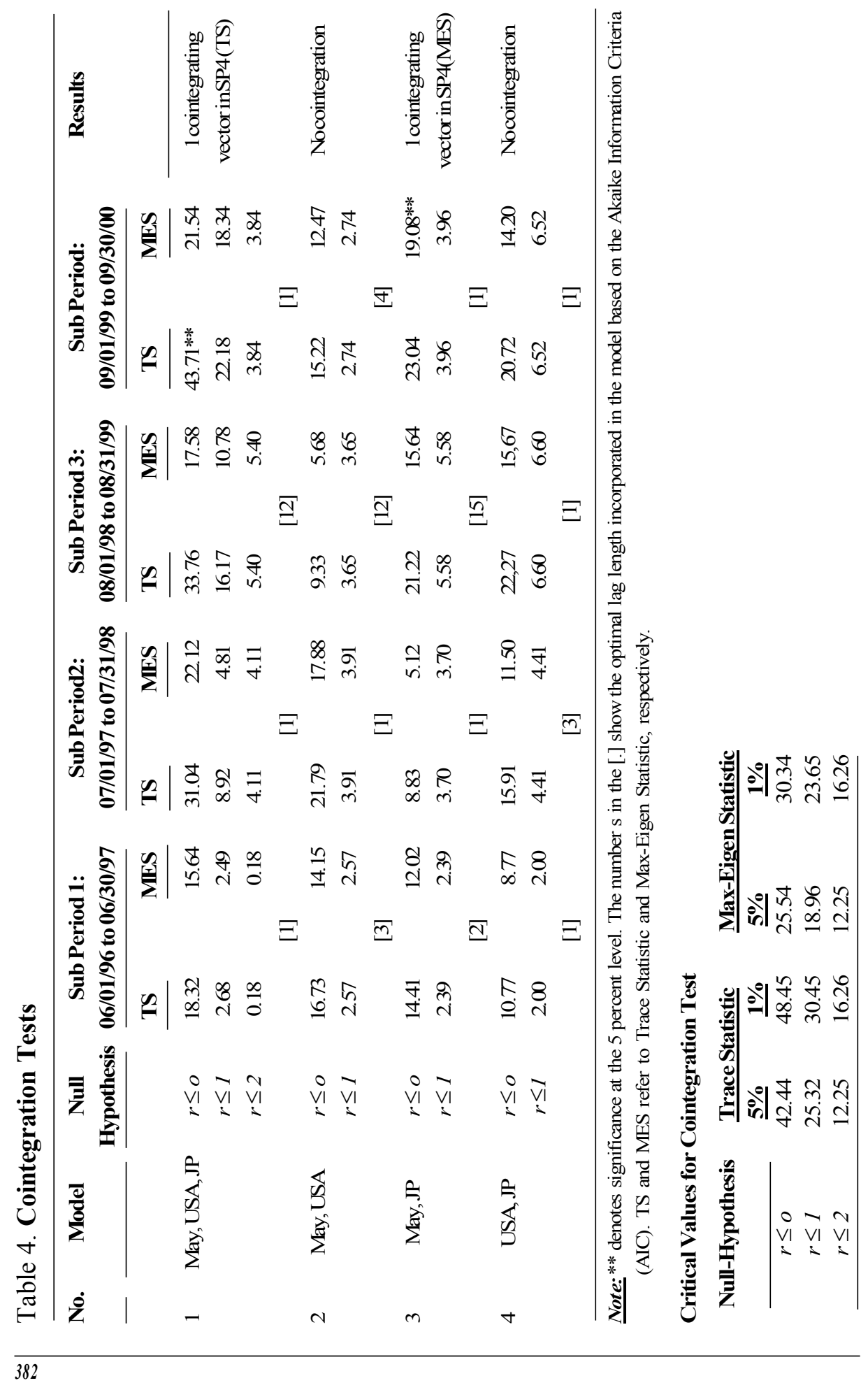


Mohd. Yusof\& Abd. Majid - Who Moves the Malaysian Stock Market

the three stock markets: Malaysia, Japanese, and the U.S. Table 4 presents the Johansen cointegration tests at the chosen log levels for all the subperiods. We chose the lag length for each model based on the AIC as stated in the table.

As may be observed from likelihood ratios (trace tests) in Table 4, Models 1 and 3 indicate that a unique cointegrating vector prevails at 5 percent significance level in subperiod 4 . This suggests that there is a comovement amongst the three national stock markets during the recovery period (after the 1997 financial crisis). Meanwhile, the Maximal eigenvalue statistics also indicate that there is a comovement between Japanese and U.S. stock markets during the recovery period 2 (subperiod 4).

$$
\begin{aligned}
\text { KLCI }= & -1.137 \mathrm{~S} \& \mathrm{P} 500- \\
& 2.868 \mathrm{TOPIX}+\mathrm{C} \\
\mathrm{KLCI}= & -3.223 \mathrm{TOPIX}+\mathrm{C}
\end{aligned}
$$

Both equations suggest negative relationships between Malaysia and U.S. and Japanese stock markets. It is interesting to note that these results seem to be consistent with Ibrahim (2003), who suggests that Malaysian and U.S. stock markets are competing. Our evidence further suggests a competing rather than complementary nature of Malaysian and Japanese stock markets.

\section{Bivariate Analysis}

This section builds upon the previous cointegration tests to precisely estimate the dynamic interactions amongst the three national stock markets. Specifically, for cointegrated cases, we employ Error Correction Models (ECMs), and for the noncointegrated series, the Error Correction Term (ECT) is omitted in the regression. Here, we present the results for pair-wise Granger causality with lags 2, 2, 11, 3, respectively, for all subperiods. We find that these lags are sufficient to whiten the noise process.

Based on the Table 5, some general conclusions on the causality can be derived: (i) the Malaysian stock market seems less affected by U.S. stock market in the period after the 1997 financial crisis; and (ii) the Japanese stock market seems to significantly affect the Malaysian stock market in the recovery period 1 .

The presence of cointegration amongst the stock markets rejects the non-causality amongst them. This means that at least one of the markets reacts to deviations from the long-run relationship. We then need to investigate whether the comovements amongst the stock markets correct for disequilibrium. Predicated on Engle and Granger (1987) and Johansen (1988), our ECMs can be expressed as follows: 
Gadjah Mada International Journal of Business, September-December 2006, Vol. 8, No. 3

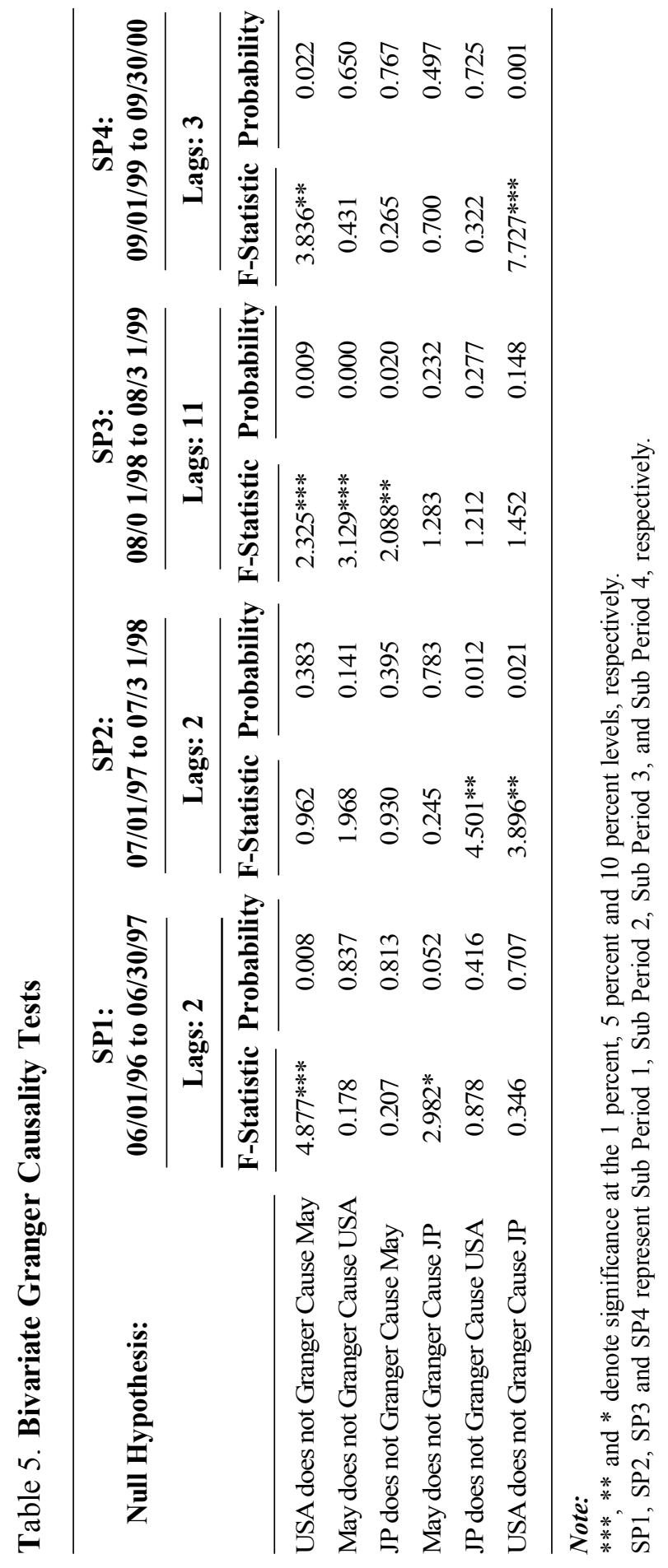


Mohd. Yusof\& Abd. Majid-Who Moves the Malaysian Stock Market

Model 1. May, US, JP

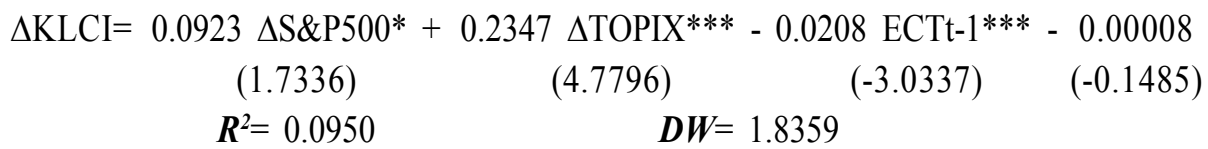

Model 3. May, JP

$\Delta \mathrm{KLCI}=0.2568 \Delta \mathrm{TOPIX}^{* * *}-0.0192 \Delta \mathrm{ECT}_{\mathrm{t}-1} * * *-0.00006$

(5.4196) (-2.9286) (-0.1154)

$\boldsymbol{R}^{2}=0.0875 \quad \boldsymbol{D} \boldsymbol{W}=1.8275$

For each of the equations above, if

Correction models allow us to distinthe error correction terms are found to be negative and significant, they further substantiate the presence of cointegration amongst the Malaysian, U.S., and Japanese stock markets as established in the system earlier.

Then, the estimated coefficients for the error correction terms in Models 1 and 3 , are $0.0208,0.019$, respectively, suggesting that the last period disequilibrium is corrected by 1.9-2.1 percent on the following day. The general performance of the models seems to be satisfactory with the expected hypothesized signs of the coefficients for the independent variables. Although the values of the R-squared are relatively low, they are still regarded as acceptable, given that the estimates are based on first differentiated values.

\section{Multivariate Analysis}

Having provided at least an insight into the bivariate causality between the national stock markets in the analysis, we now proceed to the multivariate analysis. The Vector Error guish between the short-run and longrun forms of causality. When the variables are cointegrated, in the short run, deviations from this equilibrium will feed back on the changes in the dependent variable in order to force movements towards long-run equilibrium. If the dependent variable is driven directly by this long-run equilibrium error, then it is responding to this feedback. Otherwise, it is only responding to short-term shocks to the stochastic environment.

Summarized results based on VECM formulations described earlier are presented in Table 6. For Models 1 and 3, we note that at least one channel of Granger causality is active, either in the short-run through joint tests of lagged differences or statistically significant error correction terms. The economic interpretation arising from this finding is that when there is a deviation from equilibrium cointegrating relationships as measured by the ECTs, it is mainly the changes in these variables that adjust to clear the disequilibrium. 
Gadjah Mada International Journal of Business, September-December 2006, Vol. 8, No. 3

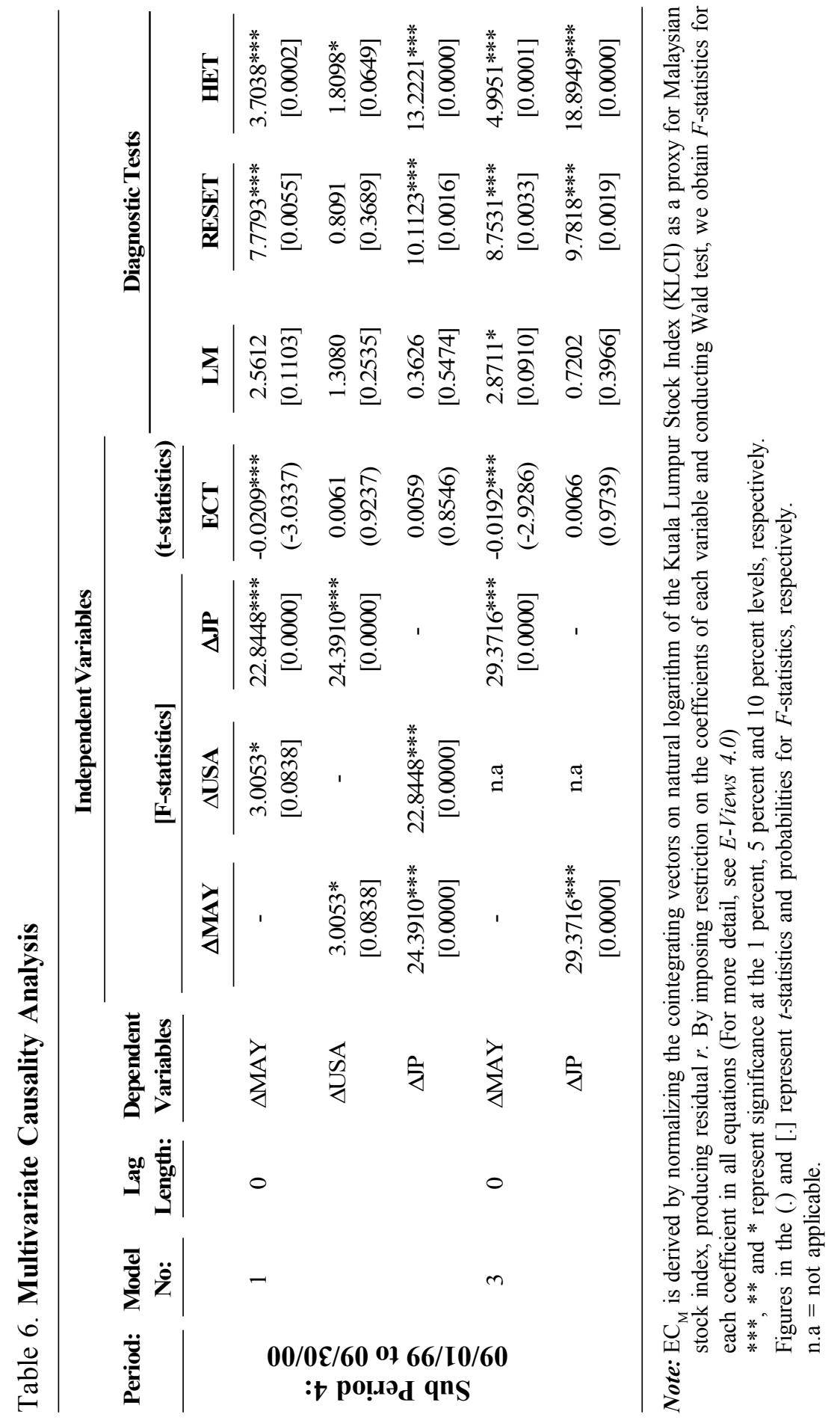


Mohd. Yusof\& Abd. Majid-Who Moves the Malaysian Stock Market

Figure 1. Multivariate Causality Analysis

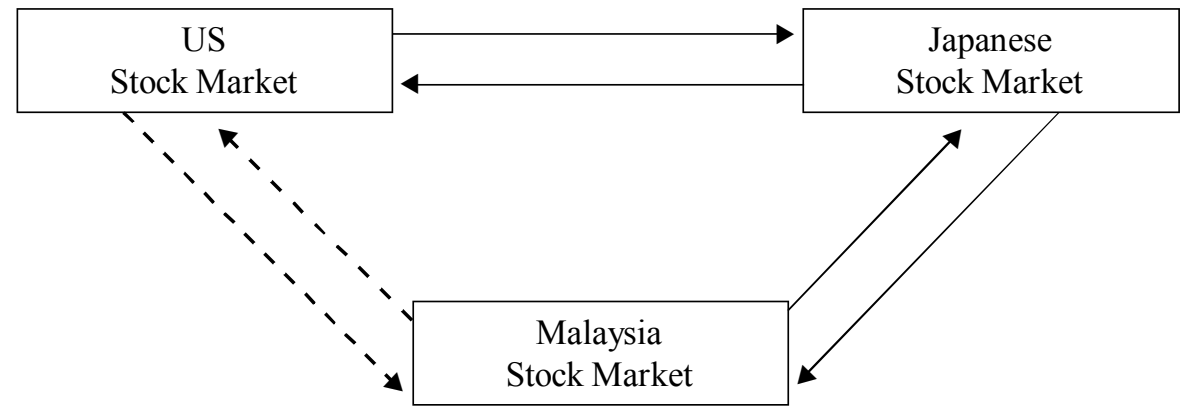

Based on Table 6 and summarized in Figure 1, some short-run causalities can be observed. At the 5 percent significance level, there seems to be a bidirectional relationship running from the Japanese and Malaysian stock markets and the Japanese and U.S. stock markets. Meanwhile, at 10 percent significance level, for the Malaysian stock market, the evidence suggests bidirectional causality running from U.S. stock market. At this juncture, we can therefore infer that the Malaysian stock market seems to be affected by both U.S. and Japanese stock markets. However, as indicated by the thicker arrow, the Japanese stock market seems to significantly affect the Malaysian stock market compared to does U.S. market during the recovery period 2 (subperiod 4 ).

The natures of the relationships amongst national stock markets can be explained by both trade and financial factors (Ibrahim 2003). Hence, the stronger the bilateral trade ties between two countries, the higher the degree of comovements should be between their stock markets (Masih and
Masih, 1999; Bracker et al. 1999; Pretorius 2002). Accordingly, the commodities and services trade linkage between two countries arising from increasing proportions of domestic exports to foreign countries and increasing proportions of domestic imports leads to a greater degree of integration amongst stock markets (Kearney and Lucey 2004).

Malaysia, being a small open economy, depends profoundly on Japan and the U.S. for its exports and imports. As indicated in the Figure 2, there seems to be a growing proportion of bilateral trade between Malaysia and Japan during the recovery periods 1 and 2 (sub periods 3 and 4). Meanwhile, for bilateral trade between Malaysia and the U.S., the proportion seems to be declining, particularly during the recovery period 2 (sub period 4). This lends support to our earlier finding that the Malaysian and Japanese stock markets are indeed cointegrated during the recovery period 2 (sub period 4). This is also consistent with the finding of Masih and Masih (1999) who opine that the 
Gadjah Mada International Journal of Business, September-December 2006, Vol. 8, No. 3

Figure 2. Malaysian Direction of External Trade (\% of Total Trade)

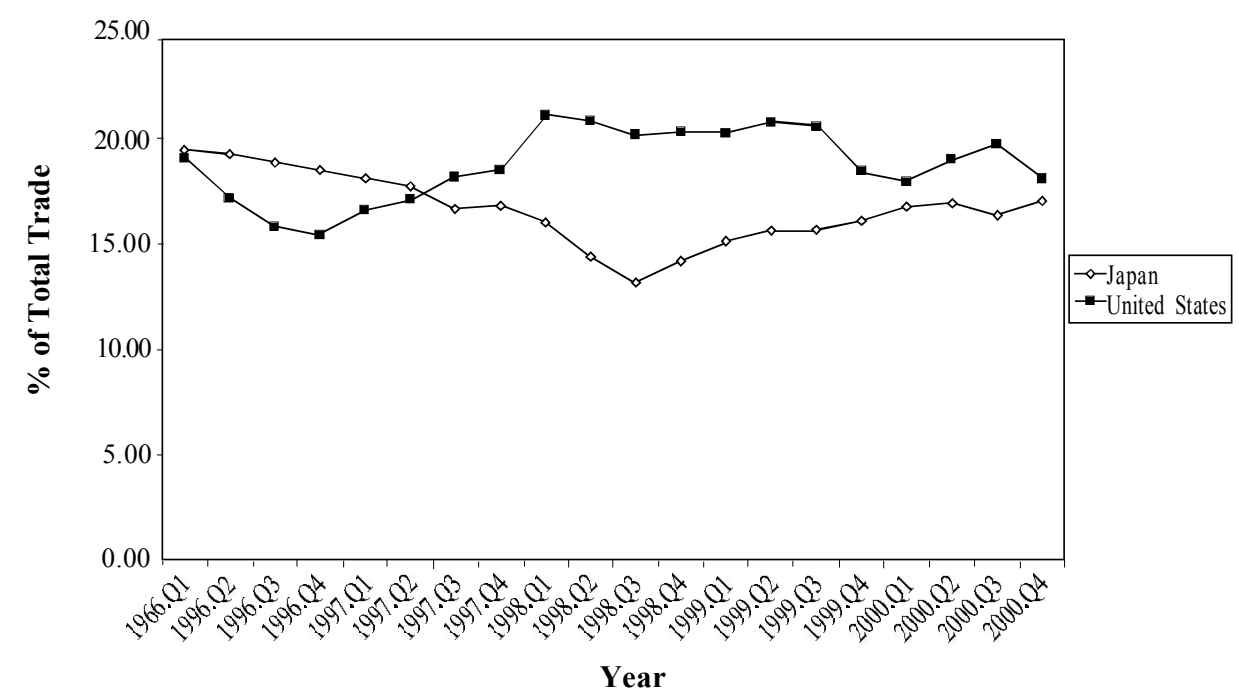

Source: Bank Negara Quarterly Statistical Bulletin (Various Issues-1996 to 2000)

higher intra-regional stock dependency amongst the Asian markets is perhaps due partly to the growing share of intra-regional trade and investment in the recent years. "Based on the Bank Negara Report (1996-2000), the equity investment by Malaysian in Japan has increased significantly on average by 7.12 percent from only RM134 million in 1996, whilst the equity investment by Malaysian in the U.S. has not shown a significant increment."

Nevertheless, the importance of financial factor tends to depend more on the perceptions of financial investors. Investors will diversify their investments across the countries if more benefits can be gained than by diversifying locally. It seems that during the 1997 financial crisis period, the financial investors in the ASEAN markets were inclined to diversify their invest- ments domestically, thereby there were no significant flows of portfolio investments across the region. The reverse trend seems to prevail in postcrisis period where the investors can gain less benefit by diversifying locally.

According to Janakiramanan and Asjeet (1998); Bracker et al. (1999); and Pretorius (2002); apart from trade bilateral dependencies, the geographic distance between different stock markets can also be an important factor contributing to a greater extent of market integration. In the case of Malaysian and Japanese stock markets, the greater degree of integration during the period of analysis could also be due to the geographic distance as compared to U.S. stock market. For instance, Janakiramanan and Asjeet (1998) provide empirical evidence that 
Mohd. Yusof\& Abd. Majid - Who Moves the Malaysian Stock Market

the geographically and economically close countries such as Australia-New Zealand and Malaysia- Singapore should exhibit higher levels of market integration.

From Table 7, we find that both Models 1 and 3 do not suffer from specification errors as indicated by LM test. However, the RESET and HET indicate problems of auto-correlation and heteroskedasticity. In general, the performance of the models is satisfactory as indicated by the sum of R-squared and acceptable DurbinWatson (DW) statistics with correct signs of coefficients for all independent variables.

\section{Variance Decompositions}

The cointegration analysis so far only suggests the long-run associations amongst three stock markets in the analysis. However, our objective is also to examine the relative strength of each variable in explaining the changes in the dependent variable. Here, we implement an unrestricted VAR model. From the model, we generate variance decompositions (VDCs) and Impulse Response functions (IRFs) to capture the relative importance of various shocks and their influences on our variable of interest. The orderings that we have chosen are: the U.S., Japan, and Malaysia. This is based on the

Table 7. Variance Decompositions

(Sub Period 4: 09/01/99 to 09/30/00)

\begin{tabular}{|c|c|c|c|c|c|c|c|c|}
\hline \multirow{3}{*}{ Day: } & \multicolumn{6}{|c|}{ Model 1: USA, JP, May } & \multirow{2}{*}{\multicolumn{2}{|c|}{$\frac{\text { Model 3: May, JP }}{\text { Order 1: JP, MAY }}$}} \\
\hline & \multicolumn{3}{|c|}{ Order 1: USA, JP, May } & \multicolumn{3}{|c|}{ Order 2: JP, USA, MAY } & & \\
\hline & $\Delta \mathbf{U S A}$ & $\Delta \mathbf{J P}$ & $\Delta$ May & $\Delta \mathbf{U S A}$ & $\Delta \mathbf{J P}$ & $\Delta$ May & $\Delta \mathbf{J P}$ & $\Delta$ May \\
\hline 1 & 1.870 & 4.724 & 93.406 & 0.583 & 6.011 & 93.406 & 6.971 & 93.029 \\
\hline 2 & 2.586 & 4.727 & 92.687 & 1.168 & 6.145 & 92.687 & 7.206 & 92.794 \\
\hline 3 & 3.990 & 4.682 & 91.328 & 2.592 & 6.080 & 91.328 & 7.238 & 92.762 \\
\hline 4 & 4.034 & 4.682 & 91.284 & 2.640 & 6.076 & 91.284 & 7.238 & 92.762 \\
\hline 5 & 4.039 & 4.683 & 91.278 & 2.645 & 6.076 & 91.278 & 7.238 & 92.762 \\
\hline 6 & 4.039 & 4.683 & 91.278 & 2.645 & 6.077 & 91.278 & 7.238 & 92.762 \\
\hline 7 & 4.039 & 4.683 & 91.278 & 2.645 & 6.077 & 91.278 & 7.238 & 92.762 \\
\hline 8 & 4.039 & 4.683 & 91.278 & 2.645 & 6.077 & 91.278 & 7.238 & 92.762 \\
\hline 9 & 4.039 & 4.683 & 91.278 & 2.645 & 6.077 & 91.278 & 7.238 & 92.762 \\
\hline 10 & 4.039 & 4.683 & 91.278 & 2.645 & 6.077 & 91.278 & 7.238 & 92.762 \\
\hline 11 & 4.039 & 4.683 & 91.278 & 2.645 & 6.077 & 91.278 & 7.238 & 92.762 \\
\hline 12 & 4.039 & 4.683 & 91.278 & 2.645 & 6.077 & 91.278 & 7.238 & 92.762 \\
\hline 13 & 4.039 & 4.683 & 91.278 & 2.645 & 6.077 & 91.278 & 7.238 & 92.762 \\
\hline 14 & 4.039 & 4.683 & 91.278 & 2.645 & 6.077 & 91.278 & 7.238 & 92.762 \\
\hline
\end{tabular}


Gadjah Mada International Journal of Business, September-December 2006, Vol. 8, No. 3

assumption that both U.S. and Japanese stock markets influence the Malaysian stock market. For robustness checks, we reverse the order with: Japan, the U.S., and Malaysia. Finally, we employ the generalized impulses which do not depend on the VAR ordering, as described by Pesaran and Shin (1998).

Table 7 provides variance decompositions for the horizon of 1-14 days. As may be noted from these variance decompositions, we can then conclude that the variations in the Malaysian stock market as measured by the KLCI respond more to shocks in the Japanese market than in U.S. market during the post-crisis period (account for about 5-7 percent of the KLCI forecast error variance after 14 days). This finding implies that the opportunities of gaining abnormal profit through investment diversification in the postcrisis period in these markets are going to diminish as the markets going towards a greater integration amongst them.

It is compelling to note that the studies on South-East Asian stock markets comovements with U.S. and Japanese markets seem to report mixed results. For instance, Daly (2003) asserts that there is little evidence of integration of South-East Asian stock markets namely Indonesia, Malaysia, Philippines, Singapore, Thailand with the advanced stock markets of Australia, Germany and the U.S. for the period of 1990 to 2001 (covering the periods both before and after the 1997 financial crisis). However, this study reveals that whilst there is some evidence of long-run integration between the South-East Asian markets, the level of integration appears to be slightly stronger in the post-crisis period. The evidence of Daly (2003) to some extent is in line with our finding. As the Malaysian stock market goes to a greater integration, especially with Japanese stock market, it implies that the two markets simultaneously adjust to new information, thereby eliminating any opportunities of gaining abnormal profits associated with lagged information processing. This finding augurs well with that of Cha and Sekyung (2000) and Abd. Majid (2005).

Furthermore, in their study, Jang and Sul (2000) report that there was no comovement in the stock markets of seven Asian countries; Korea, Japan, Hong Kong, Taiwan, Thailand, Indonesia, and Singapore in the pre-crisis period; 8 months from October $1^{\text {st }}$, 1996 to May $31^{\text {st }}, 1997$. However, the integration amongst these markets seems to increase sharply since the 1997 financial crisis. Our study seems to be consistent with this study, indicating an increased integration especially with Japanese stock market in the post-crisis period. Then, Sheng and $\mathrm{Tu}(2000)$ provide another dimension in examining the existence of cointegration relationships amongst the national stock indices of the U.S., Ja- 
Mohd. Yusof\& Abd. Majid-Who Moves the Malaysian Stock Market

pan, Singapore, Australia, Korea, Taiwan, Malaysia, Philippines, Thailand, Indonesia, and China. By employing the variance decompositions technique, the study finds that the degree of exogeneity for all countries indices has been reduced, implying that no countries are 'exogenous' to the financial crisis. Finally, based on Granger causality test, U.S. market is observed to still influence Malaysian stock market (around 4 percent) during the period of crisis, reflecting the U.S. market's persistent dominant role. Our study however points to the Japanese stock market as having persistent dominant role compared to U.S. stock market in the post-crisis period. Again, this finding corresponds with our earlier finding using correlation analysis (See Table 3).

Although our finding provides the same implication as the aforementioned studies, but it somehow appears to be different from that of Malliaris and Urrutia (1992). In fact, they find that there were no comovements amongst the major stock markets in the wake of the October crash of 1987 , but there were increased comovements during the 1987 crash.

\section{Impulse Response Functions}

We further generate the impulse response functions (IRFs) to complement our analysis based on the variance decompositions described above. In general, the overall results seem to be consistent with our earlier findings. Accordingly, we present our results based on the Order 1, Order 2 and finally the generalized impulses (Order 3).

Generally, for both the Cholesky and generalised impulses orderings, our findings from Figures 3, 4, 5, and 6 appear to reaffirm our previous findings. Firstly, Malaysian stock market seems to have an immediate negative response to shocks in the Japanese stock market. Secondly, we find a lagged negative response (generally between 2-3 days) of KLCI to shocks in S\&P 500 and gradually subsiding after the period of between 4-5 days. From this we can infer that the Malaysian stock market appears to immediately respond to the Japanese market compared to U.S. market. This further implies that any policies affecting the Japanese stock market should at least be noted by the authorities to affect the Malaysian stock market. 
Gadjah Mada International Journal of Business, September-December 2006, Vol. 8,No. 3

Figure 3. Response to Cholesky (Order 1: USA, JP, MAY)
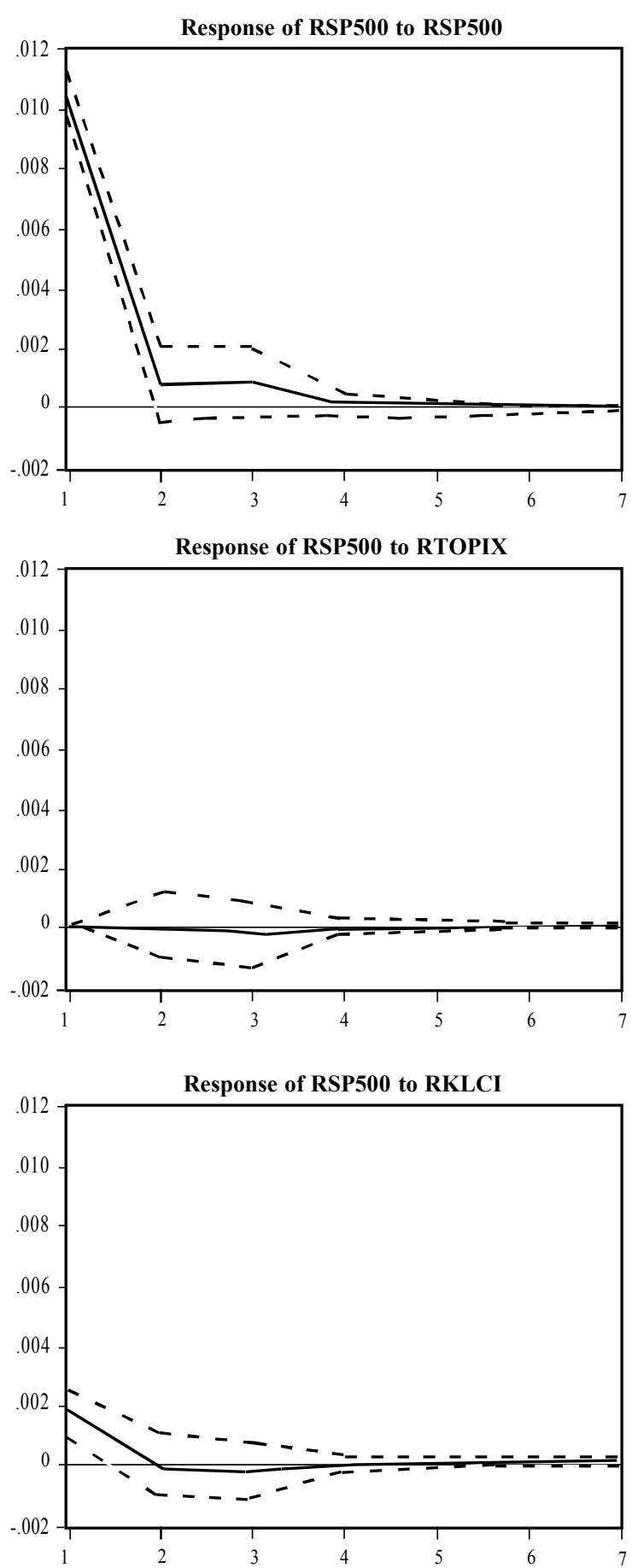
Mohd. Yusof\& Abd. Majid - Who Moves the Malaysian Stock Market

\section{Continued from Figure 3}
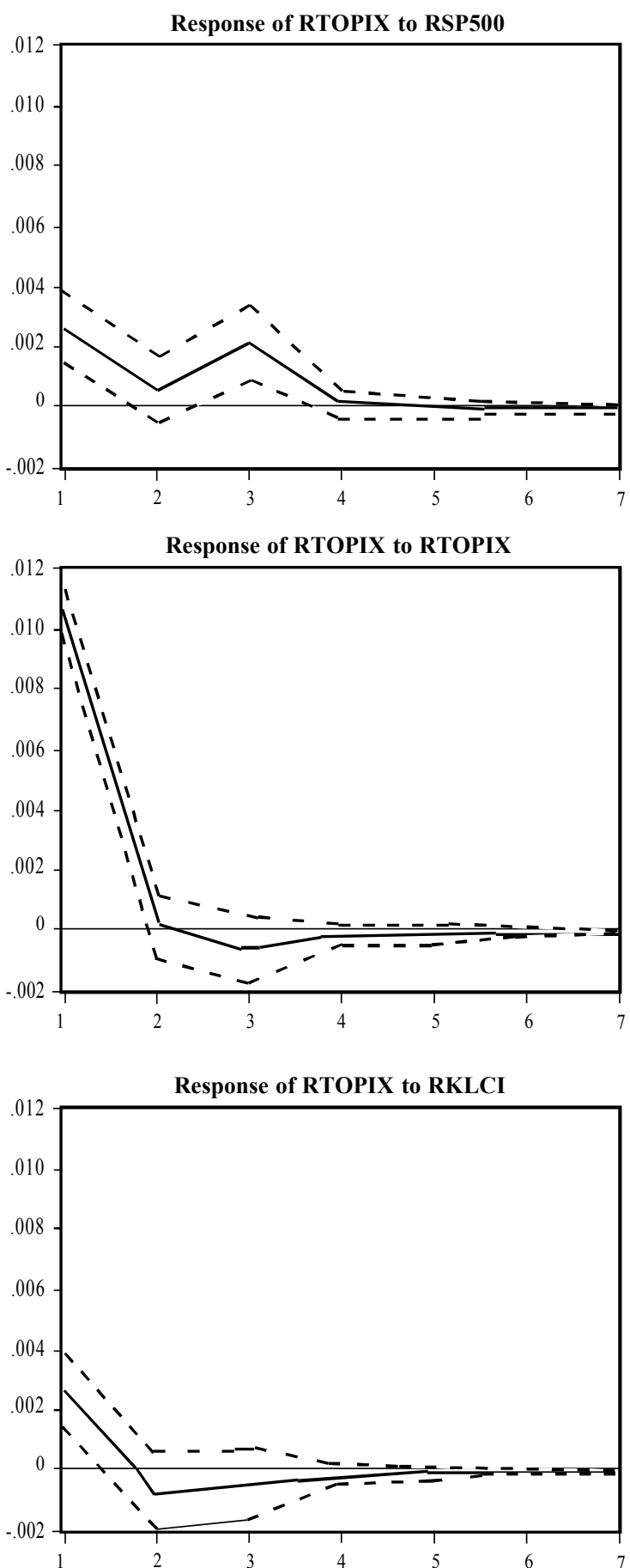
Gadjah Mada International Journal of Business, September-December 2006, Vol. 8,No. 3

\section{Continued from Figure 3}
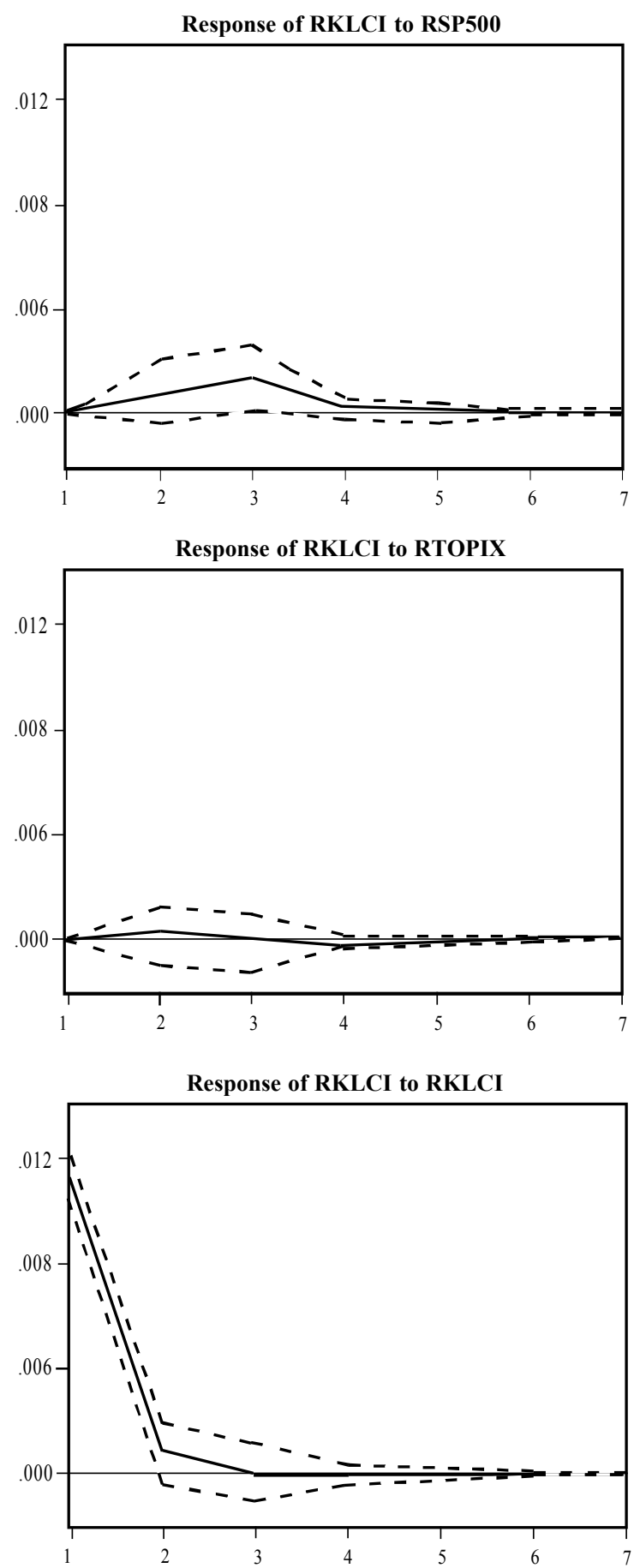
Mohd. Yusof\& Abd. Majid - Who Moves the Malaysian Stock Market

Figure 4. Response to Cholesky (Order 2: JP, USA, MAY)
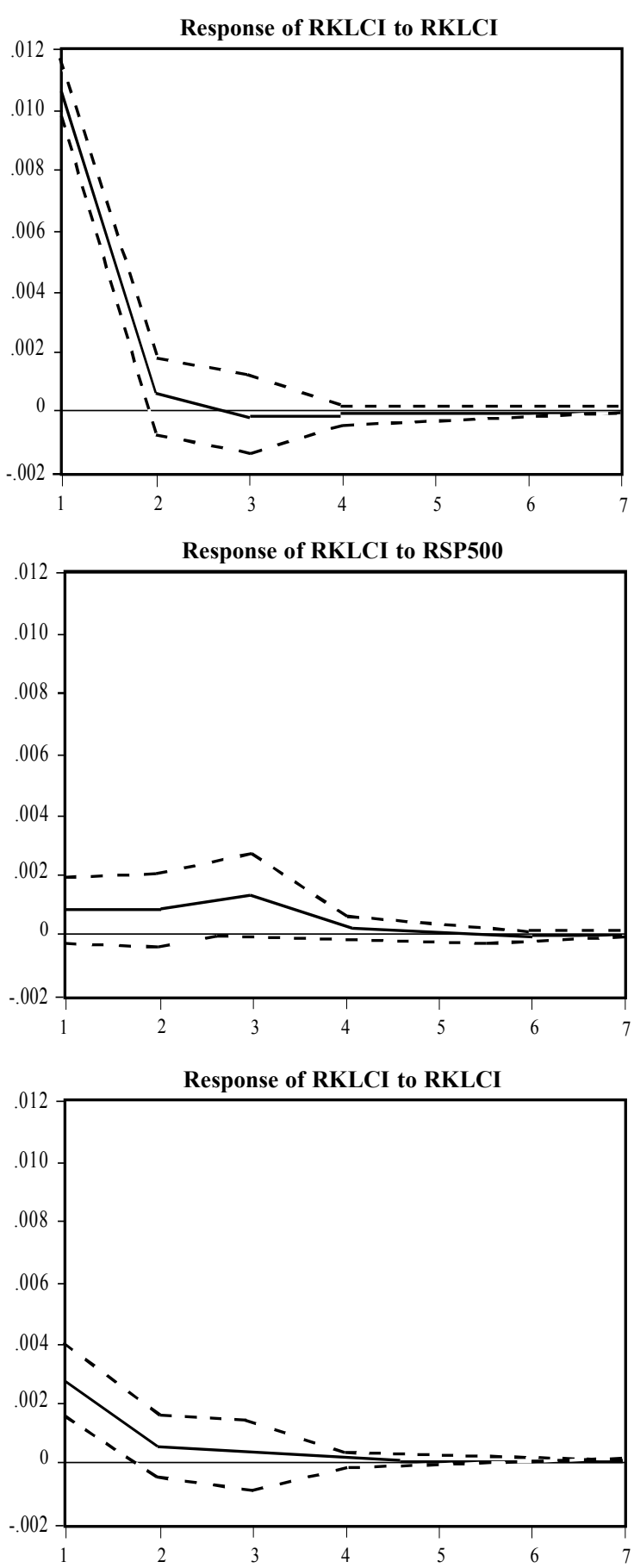
Gadjah Mada International Journal of Business, September-December 2006, Vol. 8,No. 3

\section{Continued from Figure 4}
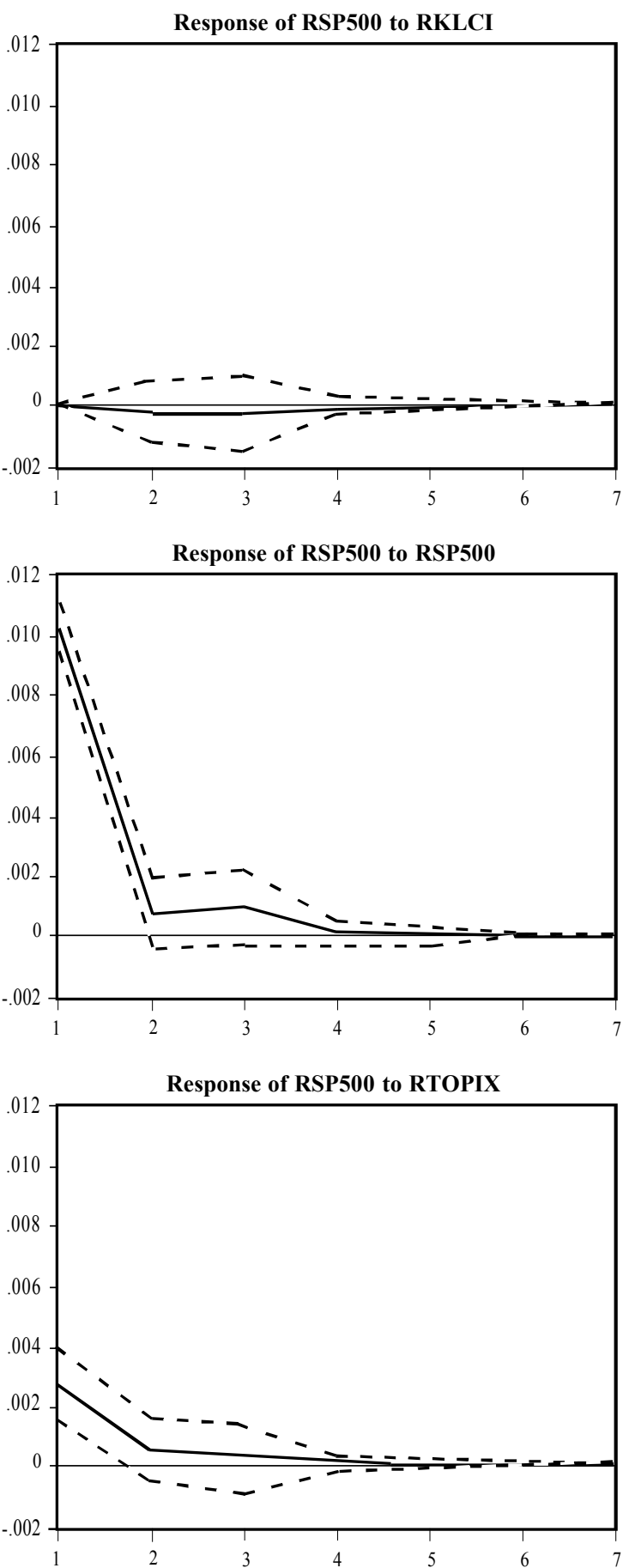
Mohd. Yusof\& Abd. Majid-Who Moves the Malaysian Stock Market

\section{Continued from Figure 4}
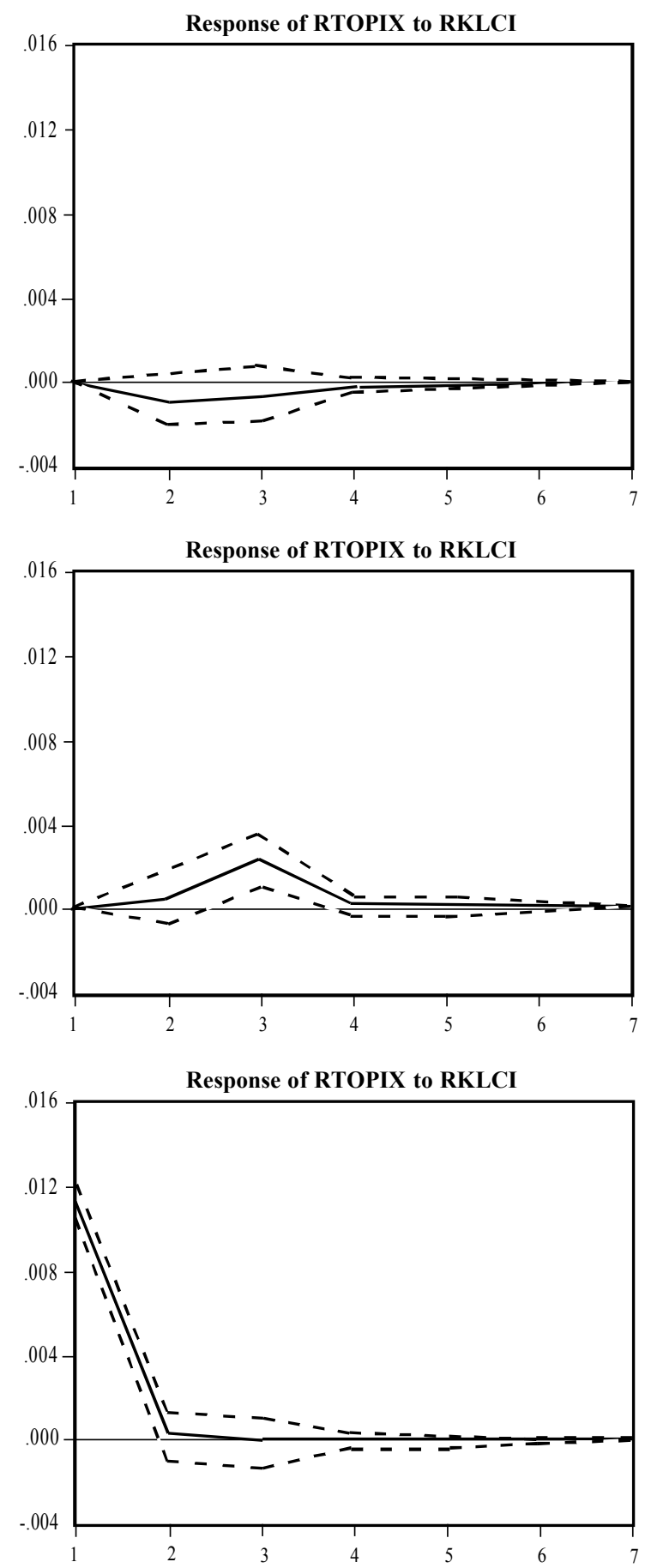
Gadjah Mada International Journal of Business, September-December 2006, Vol. 8,No. 3

Figure 5. Response to Generalized One S.D. Innovations \pm 2 S.E.
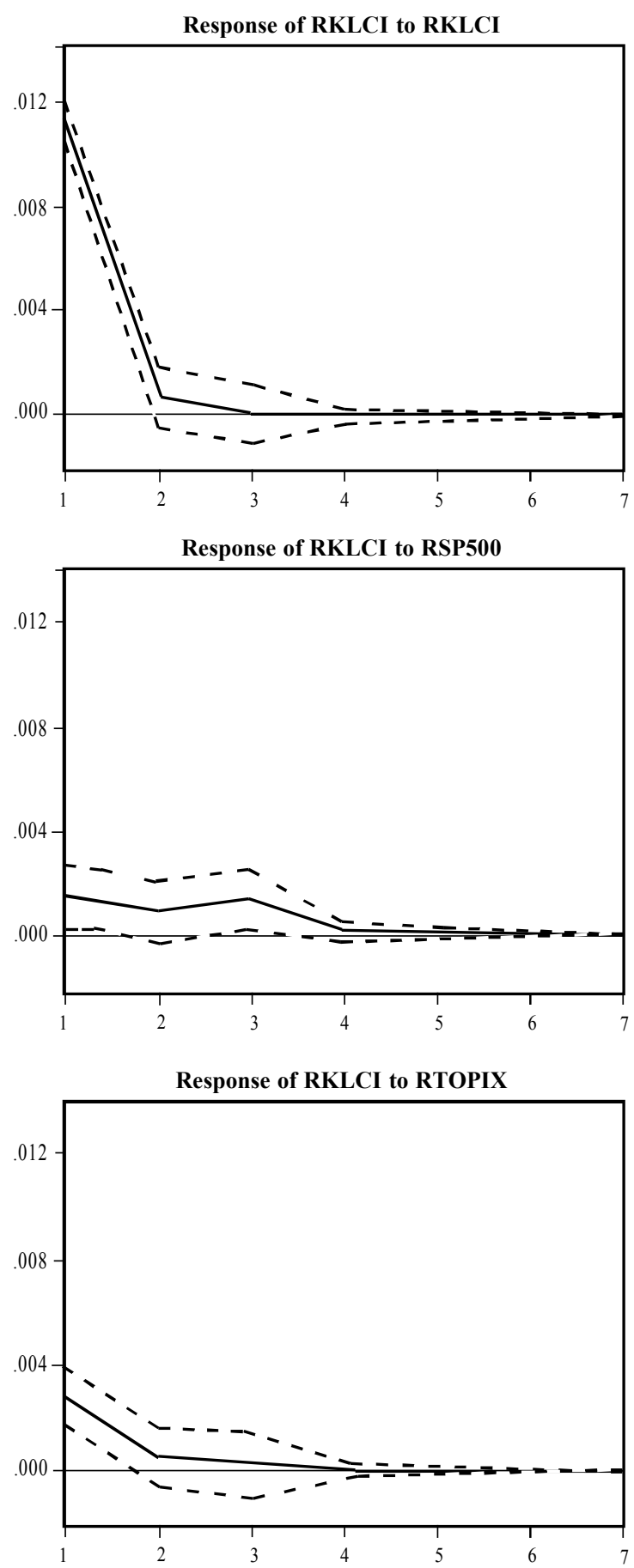
Mohd. Yusof\& Abd. Majid-Who Moves the Malaysian Stock Market

\section{Continued from Figure 5}
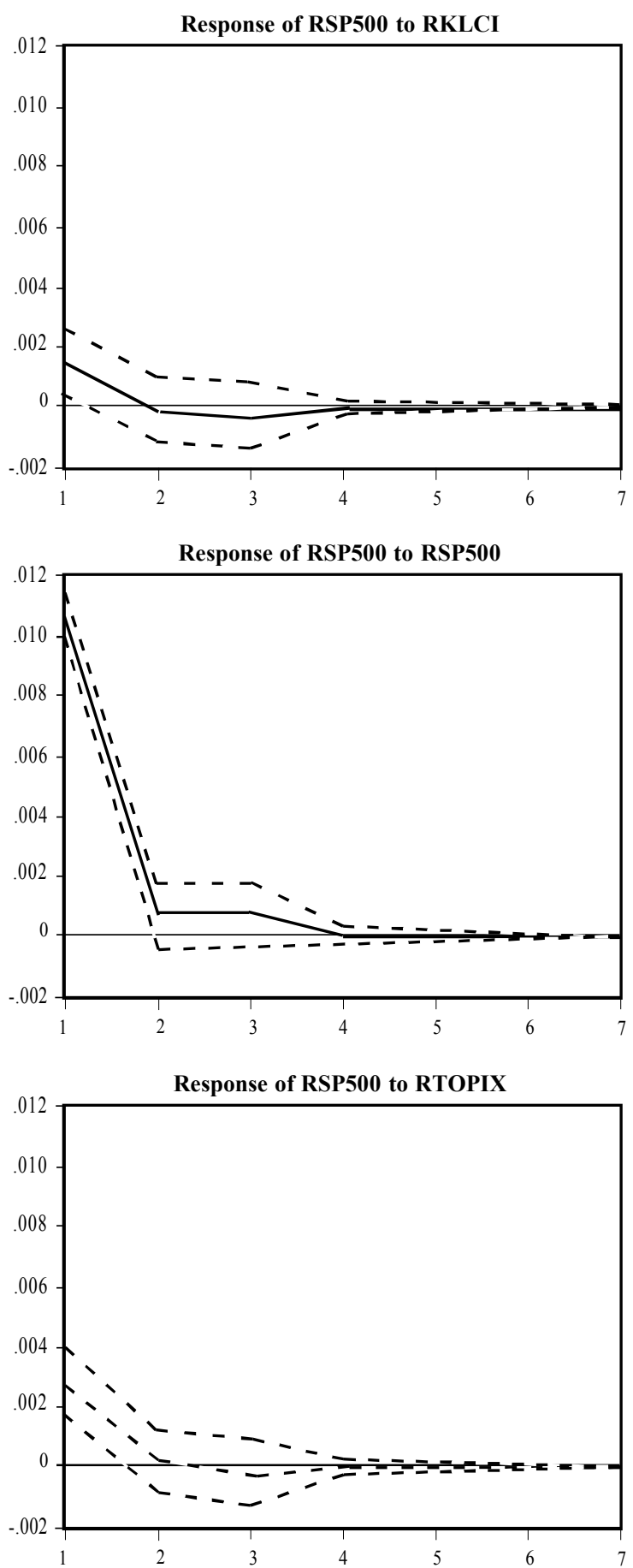
Gadjah Mada International Journal of Business, September-December 2006, Vol. 8,No. 3

\section{Continued from Figure 5}
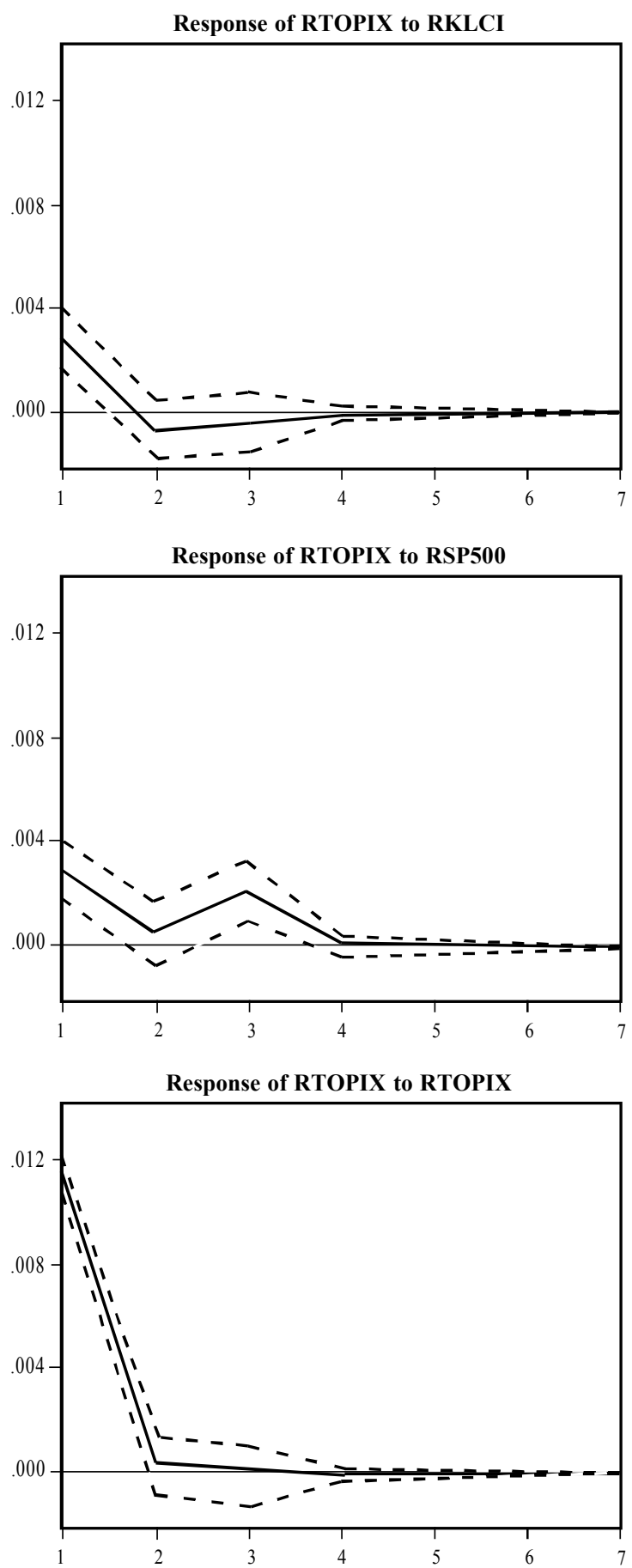
Mohd. Yusof\& Abd. Majid - Who Moves the Malaysian Stock Market

Figure 6. Response to Generalized One S.D. Innovations \pm 2 S.E.
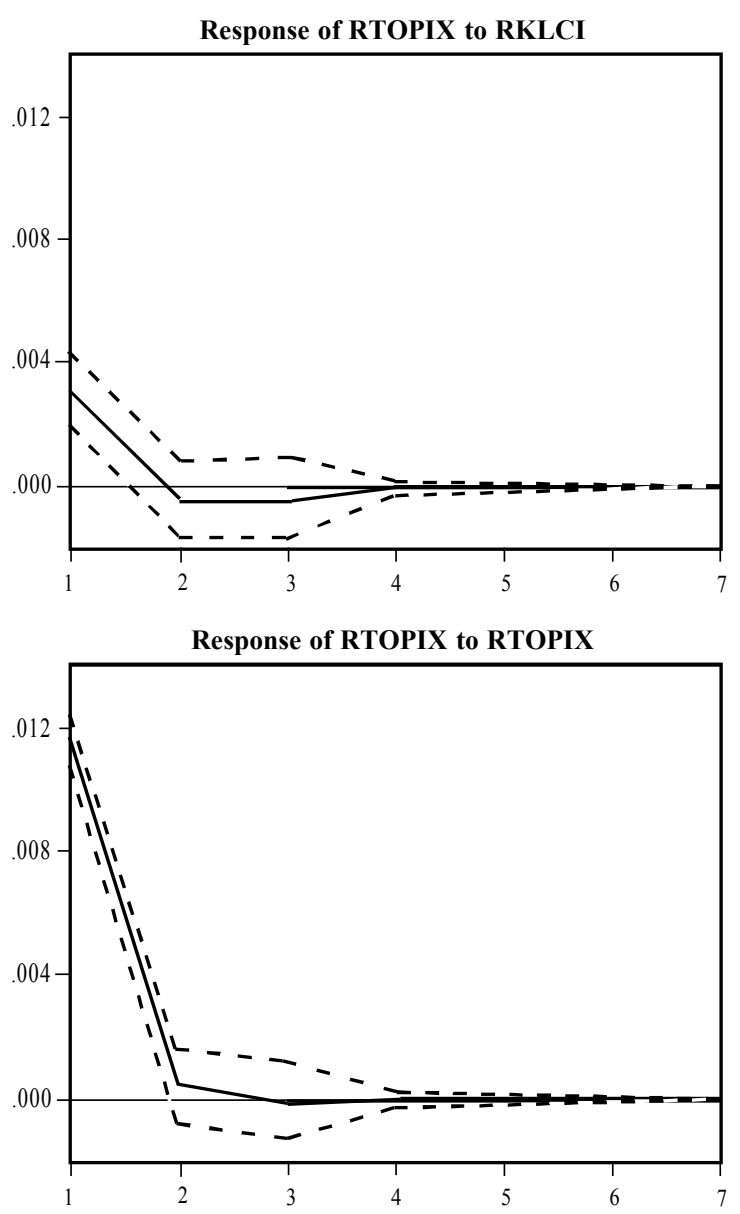

Response of RKLCI to RKLCI

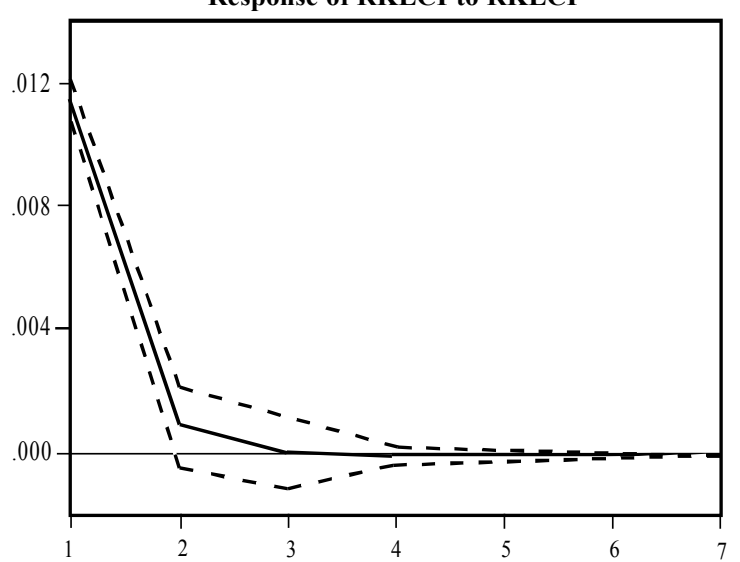




\section{Continued from Figure 6}

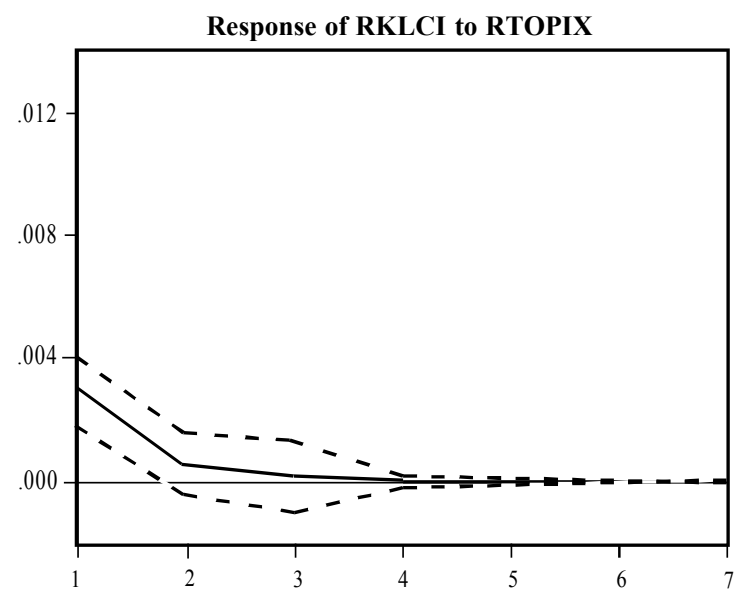

\section{Conclusion}

This paper attempts to investigate the dynamic dependence of the Malaysian stock market on two most developed stock markets in the world, the U.S. and Japan. Based on the cointegrationresults, Variance Decompositions (VDCs) and Impulse Response Functions (IRFs), we find that the Malaysian stock market is more integrated with the Japanese stock market during the post-1997 financial crisis period compared to with U.S. stock market. This could be partly due to a growing proportion of bilateral trade between Malaysia and Japan during the mentioned period. This finding seems to be consistent with the view that the stronger the bilateral trade ties between two countries, the higher the degree of comovements (Masih and Masih 1999; Bracker et al. 1999; Pretorius 2002; Ibrahim 2003; Kearney and Lucey 2004). In addition, from the financial factors, it seems that during the 1997 financial crisis period, the financial investors in the Malaysian market were inclined to diversify their investments domestically, thereby there were no significant flows of portfolio investments within the region. The reverse trend seems to prevail in the post-crisis period where the investors can gain less benefit by diversifying locally.

According to Janakiramanan and Asjeet (1998); Bracker et al. (1999); and Pretorius (2002); apart from trade bilateral dependencies and financial factors, the geographic distance between different stock markets can also be an important factor contributing to a greater extent of market integration. In the case of Malaysian and Japanese stock markets, the greater degree of integration during the period of analysis could also be due to the geographic distance as compared to U.S. stock market. 
Mohd. Yusof\& Abd. Majid-Who Moves the Malaysian Stock Market

Our finding implies that the opportunities of gaining abnormal profits through investment diversification during the post-crisis period (subperiod 4) in the Malaysian and Japanese stock markets are diminishing as the markets move towards a greater inte- gration. Eventually, for the purpose of policy making, any shocks in the Japanese stock market should be taken into consideration by the Malaysian authorities in designing policies to affect its stock market.

\section{Refererences}

Abd. Majid, M. S. 2005. Stock market integration in emerging economies: The case of ASEAN vis-à-vis USA and Japan. PhD Dissertation. Kulliyyah of Economics and Management Sciences, International Islamic University Malaysia.

Abdullah, D.A. 1998. Money growth variability and stock returns: An innovations accounting analysis. International Economic Journal. 12 (4): 89-104.

Aggarwal, R., and R. Pietra. 1998. The relationship between the US. and four Asian Stock Markets. ASEAN Economic Bulletin. 6 (1): 110-117.

Ahmed, H., and J. L. Tongzon. 1998. An investigation of economic linkages among the ASEAN group of countries. ASEAN Economic Bulletin 15 (2): 121-136.

Akdogan, H. 1991. Empirical examination of equity market integration in European community: An asset pricing model. UMI Dissertation Services. Ann Arbor, Michigan: A Bell \& Howell Company.

Bracker, K., S. Diane, and D. K. Paul. 1999. Economic determinants of evaluation in international stock market integration. Journal of Empirical Finance 6: 1-27.

Blackman, S. C., K. HoldenK, and W. K. Thomas. 1994. Long-term relationship between international share prices. Applied Financial Economics 4: 297-304.

Campbell, J. Y., and Y. Hamao. 1992. Predictable stock returns in the United States and Japan: A study of long-term capital market integration. Journal of Finance 47: 4370.

Cha, B., and O. Sekyung. 2000. The relationship between developed equity markets and the Pacific-Basin's emerging equitymarkets. International Reviewof Economics and Finance 9: 299-322.

Cheng, H. 2000. Cointegration test for equity market integration: The case of China economic area (Mainland China, Hong Kong, and Taiwan), Japan and the United States. PhD Dissertation. The School of Business of Public Management of the George Washington University. Washington, D.C.

Corhay, A., T. R. Alireza, and U. Jean-Pierre. 1995. Long-run behavior of Pacific-Basin stock prices. Applied Financial Economics 5: 11-18.

Daly, K. J. 2003. Southeast Asian Stock Market linkages evidence from pre-and postOctober 1997. ASEAN Economic Bulletin 20 (1): 73-85. 
Gadjah Mada International Journal of Business, September-December 2006, Vol. 8, No.3

Darbar, S., and P. Deb. 1997. Comovement in international equity markets. Journal of Financial Research 20: 305-322.

Dickey, D. A., and W. F. Fuller. 1979. Distribution of the estimates for autoregressive time-series with a unit root. Journal of the American Statistical Association 74: 42731 .

1981. The likelihood ratio statistic for autoregressive time series with a unit root. Econometrica 49 (4): 1057-1072.

Durand, R. B., S. K. Koh, and W. Iain. 2001. Who moved Asian-Pacific Stock Markets? A further consideration of the impact of the US and Japan. Australian Journal of Management 26 (2): 125-145.

Enders, W. 1995. Applied Econometrics Time Series. USA: John Wiley and Sons, Inc.

Engle, R. F., and Granger. 1987. Cointegration and error correction regression, estimation and testing. Econometrica 55 (2): 251-76.

Ghosh, A., R. Saidi, and K. H. Johnson. 1999. Who moves the Asia-Pacific Stock MarketsUS or Japan? Empirical evidence based on the theory of cointegration. Financial Review 34: 159-170.

Goldstein, M., and M. Michael. 1993. The integration of world capital markets. IMF Working Paper. International Monetary Fund.

Granger, C. W. J. 1986. Developments in the study of cointegrated economic variables. Oxford Bulletin of Economics and Statistics 48: 213-228.

1988. Some recent development in a concept of causality. Journal of Econometrics 39: 199-211.

Hassan, T., S. Mohamad., and A. Nassir. 2001. Learning process of a new and old futures market in the case of Malaysia. Proceedings of the Malaysian Finance Association. $3^{\text {rd }}$ Annual Symposium. International Islamic University Malaysia.

Hirayama, K., and Y. Tsutsui. 1998. Threshold effect in international linkage of stock prices. Japan and the World Economy 10: 441-453.

Hung, B. W., and Y. Cheung. 1995. Interdependence of Asian emerging equity markets. Journal of Business Finance and Accounting 22: 281-288.

Ibrahim, M. H. 2003. Macroeconomic forces and capital market integration, A VAR analysis for malaysia. Journal of the Asia Pacific Economy 8 (1): 19-40.

Ingersol, J. E. Jr. 1987. Theory of Financial Decision Making. Maryland: Rowman and Littlefield.

Janakiramanan, S., and S. L. Asjeet. 1998. An empirical examination of linkages between Pacific-Basin Stock Markets. Journal of International Financial Markets, Institutions and Money 8: 155-173.

Jang, H., and W. Sul. 2002. The Asian financial crisis and the Comovement of Asian Stock Markets. Journal of Asian Economics 13: 94-104.

Jeon, B. N., and F. G. M. Von. 1990. Growing international Comovement in Stock Indices. Quarterly Review of Economics and Finance 30: 15-30. 
Mohd. Yusof\& Abd. Majid-Who Moves the Malaysian Stock Market

Johansen, S. 1988. Statistical analysis of cointegrating vectors. Journal of Economic Dynamics and Control 12: 231-254.

Johansen, S. and Juselius. 1990. Maximum likelihood estimation and inference on cointegration - with application to the demand for money. Oxford Bulletin of Economics and Statistics 52 (2): 169-210.

1992. Testing structural hypotheses in a multivariate cointegration analysis of the PPP and UIP for UK. Journal of Econometrics 53: 211-244.

Jorion, P., and E. Schwartz. 1986. Integration vs. segmentation in the Canadian Stock Market. Journal of Finance 41: 603-613.

Kearney, C., and B. M. Lucey. 2004. International equity market integration: Theory, evidence and implications. International Reviewof Financial Analysis 13: 571- 583.

Kleimeier, S., and S. Herald. 2000. Rationalization versus globalization in European Financial Market Integration: Evidence from cointegration analyses. Journal of Banking and Finance 24: 1005-1043.

Lemmen, J. 1998. Integrating Financial Markets in the European Union. Cheltenham, UK.: Elward Elgar Publishing Limited.

Lintner, J. 1965. The valuation of risk assets and the selection of risky investments in stock portfolios and capital budget. Review of Economics and Statistics 47: 13-37.

Malliaris, A., and J. L. Urrutia. 1992. The international crash of October 1987. Causality tests. Journal of Financial and Quantitative Analysis 27 (3): 353-364.

Masih, A. M., and R. Masih. 1997. A comparative analysis of the propagation of stock market fluctuations on alternative models of dynamic causal linkage. Applied Financial Economics 7: 59-74.

.1999. Are the Asian StockMarket fluctuations due mainlyto intra-regional contagion effects? Evidence based on Asian Emerging Stock Markets. Pacific-Basin Finance Journal 7: 251-282.

Naranjo, A., and P. Aris. 1997. Financial market integration tests: An investigation using US equity markets. Journal of International Financial Markets, Institutions and Money 7: 93-135.

Palac-McMiken, E. D. 1997. An examination of ASEAN Stock Market. ASEANEconomic Bulletin 13 (3): 299-310.

Pesaran, M.H. and Y. Shin. 1998. Generalised impulse response analysis in linear multivariate models. Economics Letters 58: 7-29.

Philips, P.C.B., and P. Perron. 1998. Testing for a unit root in time series regression. Econometrica 75 (2): 335-346.

Pretorius, E. 2002. Economic determinants of emerging stock market interdependence. Emerging Markets Review 3: 84-105.

Ross, S. 1976. An arbitrage theory of capital asset pricing. Journal of Economic Theory 13: 341-360. 
Gadjah Mada International Journal of Business, September-December 2006, Vol. 8,No. 3

Sheng, H-C., and A. H. Tu. 2000. A study of cointegration and variance decomposition among national equity indices before and during the period of the Asian Financial Crisis. Journal of Multinational Financial Management 10: 345-365.

Sewell, S., S. Stansell., and I. Lee. 1996. Using chaos measures to examine international capital market integration. Applied Financial Economics 6: 91-101.

Sharpe. W. F. 1964. Capital asset prices: A theory of market equilibrium under the condition of risk. Journal of Finance 19: 425-442.

Sim, C. 1980. Macroeconomics and reality. Econometrica 48 (1): 1-49.

Stehle, R. 1977. An empirical test of the alternative hypotheses of national and international pricing of risky assets. Journal of Finance 32: 493-502.

Taylor, M., and I. Tonks. 1989. The internationalization of stock markets and the abolition of U.K. exchange control. Review of Economics and Statistics: 332-336.

Thomas, R. L. 1997. Modern Econometrics: An Introduction. Essex: Addison-Wesley. Longman Limited.

Wheatley, S. 1988. Some tests of international equity integration. Journal of Financial Economics 21: 177-212. 